Article

\title{
Semantic Network Analysis of Legacy News Media Perception in South Korea: The Case of PyeongChang 2018
}

\author{
Sung-Won Yoon ${ }^{1}$ and Sae Won Chung ${ }^{2, *}$ \\ 1 Division of Business Administration, The University of Suwon, Hwaseong-si 18323, Korea; \\ syoon@suwon.ac.kr \\ 2 Graduate School of International Studies, Korea University, Seoul 02841, Korea \\ * Correspondence: swchung37@korea.ar.kr; Tel.: +82-2-3290-5323
}

Received: 5 October 2018; Accepted: 26 October 2018; Published: 2 November 2018 updates

\begin{abstract}
This paper aims at exploring how conservative and liberal newspapers in South Korea framed PyeongChang 2018 directly. Our research questions addressed four points: first, different attitudes of conservative and liberal newspapers in the PyeongChang news reporting; second, their success and failure in influencing public opinion; third, South Koreans' perceptions on PyeongChang 2018; and fourth, South Korean public reliance on the newspapers. To investigate the framing differences, we employed a big data analytic method (automated semantic network analysis) with NodeXL (analytic software). Conclusively, we were able to find out four main findings. First, the conservative media showed pessimistic attitudes to the Olympics, and the liberal media did conversely. Second, despite the conservative media's resourcefulness, they could not succeed in influencing public opinion. Third, the conservative media perceived the Olympics as an undesirable event, but the liberal media did the Olympics as a significant event for further peace promotion. Fourth, the conservative media's framings did not considerably influence upon the public opinion. As a conclusion, the public are no longer passive recipients of the messages from the media. Instead, they tend to selectively accept the information from the media based on 'collective intelligence'. This trend provides a significant implication for enhancing the sustainability of the media environment in South Korea.
\end{abstract}

Keywords: big data analytic methods; semantic network analysis; framings; NodeXL

\section{Introduction}

The XXIII Winter Olympics held from 9 to 25 February 2018 in PyeongChang County, South Korea drew a considerable amount of attention from global media. The Olympics, commonly known as PyeongChang 2018, was a highly striking event not simply because it accommodated the largest number of participating countries, people, and games in the Olympic history. It was because of the 'peaceful mood' created between two Koreas as realised in introducing a joint-marching in the opening ceremony, establishing a unified Korean female ice hockey team, and inviting North Korean delegates to the opening and closing ceremonies. It was thus even expected that North Korean and US representatives might meet for talks during or after the Olympics. By enhancing the expectation on the peace settlement in the Korean peninsula, such peaceful mood resulted in official talks between North and South Koreas, and also between Pyongyang and Washington in the end. In this regard, the Olympics has created a significant image as a "Peace Olympics". However, such image bears vast disparities between major media in South Korea in accordance with their political orientations. On the one hand, the conservative media framed this event 'negatively' by projecting the images 
of this event as 'Pyongyang Olympics' or an inappropriate event. On the other hand, the liberal media framed this event 'positively' by giving positive evaluations enforcing its peacemaking aspects. This paper aims at exploring how differently these two types of Korean media framed this event. This study employs automated semantic network analysis, which is one of alternative content analysis methods [1]. This method is useful in representing the content of the message as a network of objects, such as positive and negative accounts of a certain object [1]. The schematic representation of semantic network analysis is presented in Figure 1.

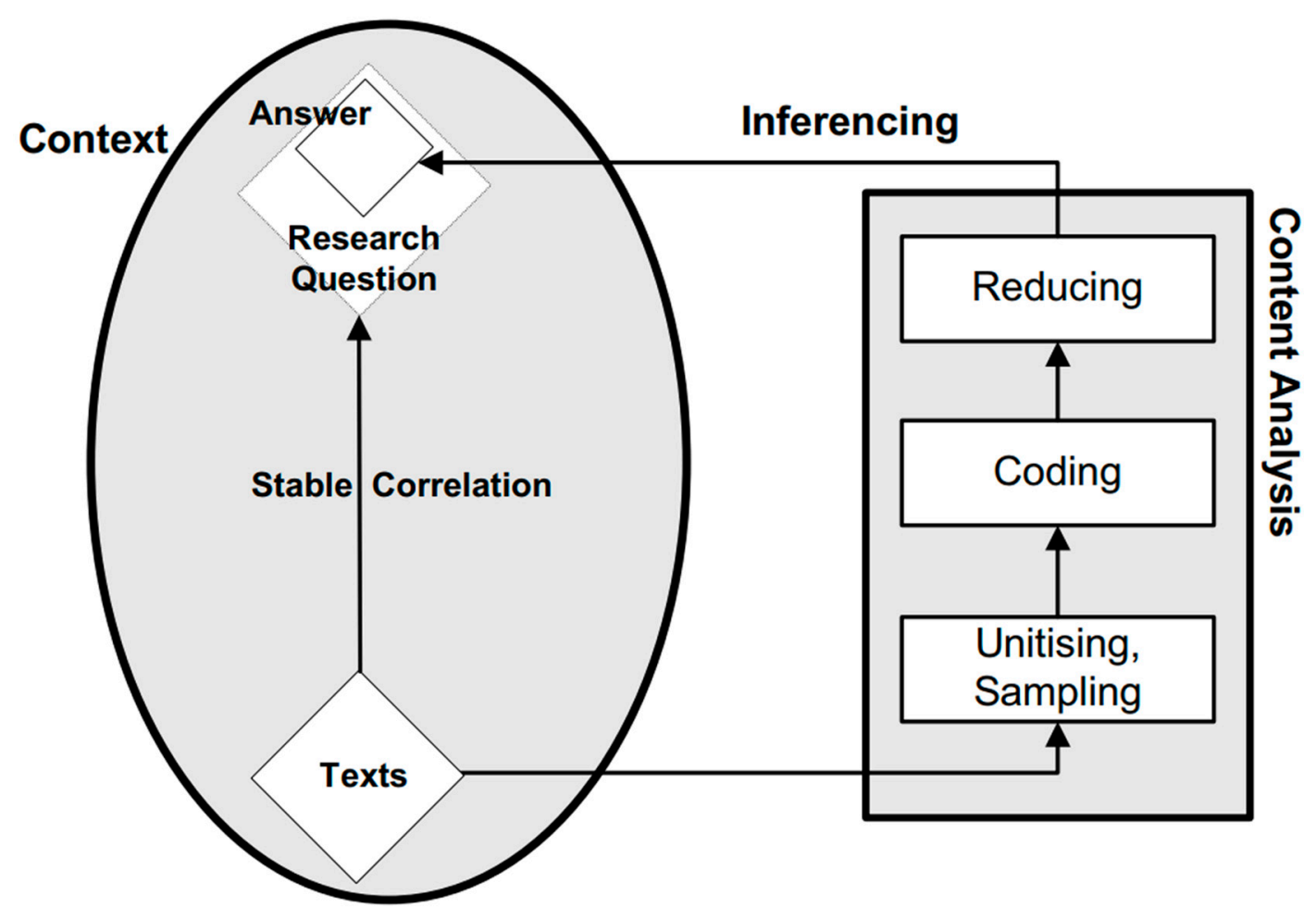

Figure 1. Semantic network analysis [1] (p. 17).

The contribution of this study lies in providing a new interpretation to PyeongChang 2018 based on semantic networks extracted from news media texts. Empirical studies on Pyeongchang 2018 have touched upon event preparation or civic participation. Especially, in 2011, when the hosting the PyeongChang Olympics was confirmed, most studies were conducted in order to prepare a plan for regional development by analysing the hosting environment of the PyeongChang Olympics [2-6]. Alternatively, in the preparation of hosting the PyeongChang Olympics, the regional residents' willingness to cooperate can have a positive influence in terms of regional development and the diffusion of sport culture [7]. However, there is no study on the media attitudes and their subsequent formation of public opinion about this event. In this vein, this study can be timely and significant to some extent. By conducting semantic network analysis, this study can suggest another novel way of interpreting this event. Semantic network analysis seeks to explore what are the keywords in the media discourse (vertices) and their relations among themselves (edges) [8]. Semantic network analysis is a standardised method of extracting essential representations from huge amount of unstructured data [8]. Hence, the research outcomes of this study can suggest extended interpretation of this event in social context and structure (Figure 2). 


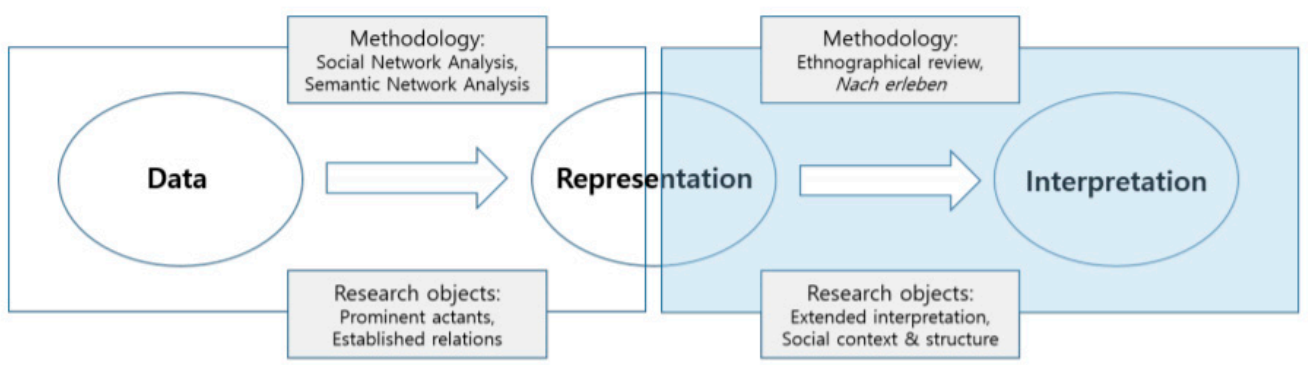

Figure 2. The role of semantic network analysis in interpretive sociology [8] (p. 11).

This paper consists of five sections. First, it reviews empirical literatures on press partisanship in South Korea. Second, a theoretical framework based on two relevant theories-framing theory and graph theory-is presented. Then, the third section concerns our big data analytic methods-automated semantic network analysis. The fourth section elaborates our data profiles, such as the volume of data, data collection period and the analysis process. Fifth, this paper presents our research findings based on our methods. Finally, the differences between the research findings and the public perceptions based on public opinion surveys on PyeongChang 2018 are discussed.

In investigating media framings about PyeongChang 2018, the following four research questions were addressed in Table 1.

Table 1. Research questions of this study.

\begin{tabular}{cl}
\hline Research Question 1 (Q1) & $\begin{array}{l}\text { How have the conservative and the liberal newspapers shown their } \\
\text { attitudes to PyeongChang 2018 in their news framings? } \\
\text { Optimistically or pessimistically? }\end{array}$ \\
\hline Research Question 2 (Q2) & $\begin{array}{l}\text { Which type of newspapers was successful in influencing public } \\
\text { opinion about PyeongChang 2018? Conservative or liberal? }\end{array}$ \\
\hline Research Question 3 (Q3) & $\begin{array}{l}\text { How did the South Korean public perceive PyeongChang 2018? } \\
\text { Positively or negatively? }\end{array}$ \\
\hline Research Question 4 (Q4) & $\begin{array}{l}\text { Why did the South Korean public buy more of a particular type of } \\
\text { newspapers (conservative or liberal)? }\end{array}$ \\
\hline
\end{tabular}

Based on these research questions, we drew out four hypotheses. They are as follows:

Hypothesis 1 (H1). The conservative media would have applied pessimistic framings to PyeongChang 2018 by selecting its negative aspects which reflect the conservative media's perceptions of this event. Conversely, the liberal newspapers would have taken opposite stances by choosing positive aspects of this event.

Hypothesis 2 (H2). The conservative media would have been more successful than the liberal ones in influencing a public opinion. It is because the conservative newspapers have larger readerships than the liberal ones. The conservative newspapers can disseminate their intended messages to their readers, and the public is more likely to accept the framings created by the conservative media.

Hypothesis 3 (H3). Considering the framing exposure by the conservative media, the South Korean public would have perceived PyeongChang 2018 Olympics negatively rather than positively.

Hypothesis 4 (H4). The South Korean public would have been influenced by the conservative media's framings. It is because the conservative newspapers are more resourceful than the liberal ones in terms of their provocative framings out of careful lexical choices. 


\section{Literature Review}

\section{Partisanship of South Korean Press and Framing}

Much has been studied extensively on the impact of press partisanship on media framing. Press partisanship refers to a consistent position and attitudes toward the social structure (such as power structure, economic distribution structure, and so on) which is formed through the consideration about the self's position of his or her values, experience and society, and public issues which influenced such social structure [9] (pp. 113-114). Press partisanship can be understood in the journalism as maintaining neutral attitudes [9] (pp. 113-114). Kahn and Kenney investigated US media editorials and other news items during 60 Senatorial election campaign periods to probe press partisanship. They suggested that the editorials and news articles are closely related with newspaper company owners' and newsmakers' political orientations [10]. In addition, their beliefs and political orientations are found in their biased framings in reporting their news articles [10]. Shoemaker and Reese also pointed out that most of the linguistic and visual information media delivers are generally influenced by the factors such as the preferences of the news producers or the news company not to mention the dominant ideology of the society [11]. Press partisanship could cause a social division and conflict in this regard [12].

In South Korea, press partisanship has became an issue since Kim Dae-jung's administration $[13,14]$. Press partisanship in South Korea is considered to have been intensified due to three causations [9] (pp. 124-128). First, it resulted from a series of hegemony struggles from a power shift. Right after gaining its power from the conservative government, Kim Dae-jung's liberal government conducted media reformation. By strengthening the standard of social transparency and procedural justification, this reformation put those who were privileged from the former governments into a critical situation. In this vein, such change gave the newspaper owners and social elites a feeling of crisis because they were the privileged members of the stable regime until the power shifted. Consequently, this transformation has strengthened press partisanship in South Korea.

Second, it arose from political parties' undemocratic nature. At the time of political democratisation in South Korea, political parties were not able to resolve newly emerging social conflicts. Instead of political parties, it was media that played a mediating role. This is believed to have strengthened press partisanship in South Korea. However, as media tried to play mediating or intervening roles instead of their original role of a messenger, they have often either exaggerated or concealed certain facts in order to represent a particular stakeholder's interests [15].

Third, press partisanship derived from the particular environment of the Korean newspaper industry. The latter has been more interested in extending their realm of political influence than securing loyal readership by producing instructive articles. This seems to have been caused by the excessively competitive nature of the media industry [9] (pp. 124-128).

Regarding the political landscape of South Korean media, there are two opposing camps-conservative camp (i.e., Chosun Ilbo, JoongAng Ilbo and DongA Ilbo, for instance), and liberal camp (i.e., The Hankyoreh and The Kyunghyang Shinmun, for instance). Both Ilbo and Shinmun mean 'newspapers' in Korean. Among these conservative newspapers, Chosun Ilbo and DongA Ilbo were established in the 1920s, in the middle of the Japanese colonial times. Since then, they have become representative conservative media. JoongAng Ilbo was established by Samsung in 1965 and became independent from it in 1999. The liberal newspapers were established much later than the conservative newspapers since South Korea's democratisation in 1987. The Hankyoreh was established in 1988. The Kyunghyang Shinmun became a liberal newspaper when its ownership was changed from Hanhwa (one of the conglomerates in Korea) to the employees of the newspaper. South Korean press partisanship became more evident when The Hankyoreh was established as the first liberal newspaper in South Korea. Regarding political orientation, three abovementioned conservative newspapers possess $70 \%$ of Korean readership; liberal newspaper possesses less than 10 percent of it [9] (p. 108). 
Then, what kind of influence has Korean press partisanship made upon the news production process? Several case studies have been conducted on a range of issues. Most representative cases include media coverage of the North Korean crisis, North-South conflict, and security of the Korean peninsula [16-20]. Notably, Kim and Roh analysed the editorials of Chosun Ilbo, DongA Ilbo, The Hankyoreh and The Kyunghyang Shinmun published from 2008 to February 2010. They argued that the apparent differences were found between different political orientations in reporting North Korean issues. They analysed the editorials' political ideology by focusing on their respective views on 'Progressive Party', 'Korea-US relations', and 'National Security Law' [20]. In each theme, different newspapers framed the issues differently based on their political orientations. In dealing with South Korea's aid to North Korea, DongA Ilbo, and Chosun Ilbo covered the issue with conservative framings and The Hankyoreh did with liberal framings [19].

In fact, press partisanship may not be an issue to be criticized unless the media do not seriously distort the truth [9] (p. 114). One might plausibly request public media organisation to discard their partisanship and keep their neutrality. However, it is almost impossible to request private media to give up their own partisanship [9] (p. 114). Basically, such diverse partisanship of media could be helpful to provide their diverse perspectives to the readers, as is a positive function of media [9] (p. 114). However, South Korean press partisanship was prevalent not only in 'ideological' issues, but in any controversial issues related to the government's policies as well. Some of the exemplary cases include the coverages on the corruptions of presidential families [21], the evaluations on the current government and president [22], South Korea's import of US beef [23], the prospects on possible economic crisis in South Korea [24], the introduction of comprehensive real estate tax and the abolition of patriarchal family system [19], and so on. Furthermore, partisanship is also strikingly captured in a wide range of policy areas such as political, diplomatic, economic, legal, educational, labour, taxation and welfare, and so forth.

According to Shoemaker and Reese's model, the government can be the external factor which influences framing media contents [11]. In other words, when the media have a political orientation different from the current government's, they are very likely to face a series of conflicts. The incumbent government may pressurise them to delete or amend some contents of news articles, whilst the latter may negatively depict the former's performances. Even though reporting on the government is the media's official and formal task, their news collecting activities are normally performed based on their private relationships [25]. Hence, irrespective of the presence of the government's pressure, there may be some sorts of self-controls by journalists or media company who were aware of the aftermath their candid coverage may cause [25]. In addition, media coverage is highly influenced not only by the media's political orientations but also their political compatibility with the government's [26]. Table 2 sums up a media-government relationship matrix based on their compatibility of their political orientations.

Table 2. Media-government relationship [26] (p. 164).

\begin{tabular}{cccc}
\hline \multirow{2}{*}{ Media-Government Relationship } & \multicolumn{2}{c}{ Political Orientations of the Regime } \\
\cline { 2 - 4 } & Conservative & Conservative & Liberal \\
\hline \multirow{2}{*}{ Media } & Liberal & I. Compatible & II. Incompatible \\
\cline { 2 - 4 } & III. Incompatible & IV. Compatible \\
\hline
\end{tabular}

Media-government relationships can be interpreted as either 'compatible' (I and IV) or 'incompatible' (II and III). When they have a compatible relationship, the media will show supportive attitudes towards the government's policies. Otherwise, the media will show negative and opposing attitudes toward the government's policies.

In this context, this study aims to investigate comprehensively how the newspapers in two opposing camps (conservative vis-à-vis liberal) in news framing. By looking into the case of 
PyeongChang 2018, we would like to address how the newspapers in each camp differentiated their attitudes in their news coverage.

\section{Theoretical Framework}

\subsection{Framing}

Framing is "to select some aspects of a perceived reality and make them more salient in a communicating text" [27] (p. 52). Framing's distinctive aspects come out of its applicability effects [28]. This effect becomes valid when the audiences accept the message exposed by the media [28]. For instance, if the news message suggested a framing about the connection between tax policy and unemployment rates, the audience might consider about the applicability of unemployment rates to tax issues [29]. In other words, issue salience from the media has a certain amount of impact upon the audience's process of cognition process. Based on this theoretical base, this paper explores how representative media in South Korea framed PyeongChang 2018 in connection to the peace and security issue of the Korean peninsula. Then, the media framings are composed with the South Korea's public opinion to the issue. D'Angelo's study presents the algorithm of frame construction flow, framing effects flow and frame definition flow (Figure 3) [30]. This study suggests the importance of diversified methods of framing analysis [30]. In this regard, automated semantic network analysis can be one of the helpful approaches showing how the framings were constructed and connected to each other from the working out the constellation of the groups of the salient words in the news texts.

\section{[1]}

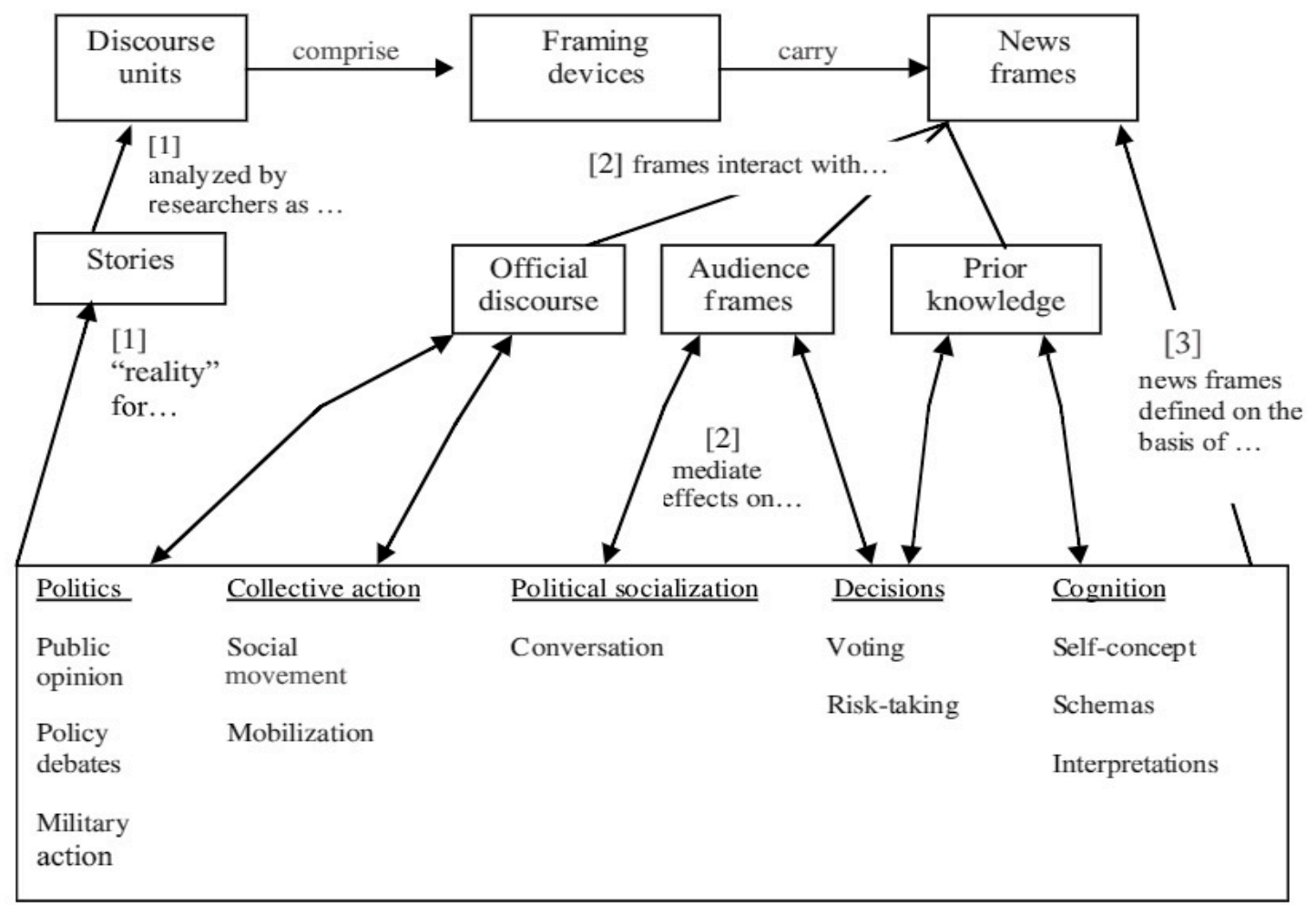

Note. [1] = Frame construction flow; [2] = Framing effects flow; [3] = Frame definition flow.

Figure 3. A model of the news framing process [30] (p. 880).

The framings exist in "located lexical choices of codes" [31] (p. 59), and can be retrieved from the most frequently mentioned certain words (or phrases) within the news texts. In recent years, there have been several accounts that point to the exploring reference words which are closely related to thematic framings. Fillmore and Atkins explored the risk frame by indicating the associate words such as danger, peril, hazard, venture, gamble, risky, perilously and so on [32] (pp. 79-80). Nerlich and 
Koteyko explored associate frames regarding carbon reduction activism in the UK by focusing on the lexical devices. They coded "carbon debt" into the finance framing, "carbon living" into the lifestyle framing, "carbon sinner" into the attitude framing [33] (p. 211). Degani focused on exploring framings by focusing on the association of lexical choices within Obama's speeches [34]. The results of these studies indicate the framing constitutes a group of reference lexical items. However, these studies do not present the overview of such connectedness. To show such connectedness, some scholars employed semantic network analysis using a computer-assisted method. Such analysis is useful regarding indicating an overview of framings based on clear visualisation established by analytic software. After addressing graph theory, this paper will introduce and review automated semantic network analysis.

\subsection{Graph Theory}

Graph theory is the study of graphs. A graph consists of points (nodes or vertices) and lines (edges or relations). This theory originated from Euler's analysis of his Königsberg (now Kaliningrad Russia) bridge problem in 1736 [35]. The problem was "can one cross all seven bridges and never cross the same one twice [35]?" A background map is provided in Figure 4 below.

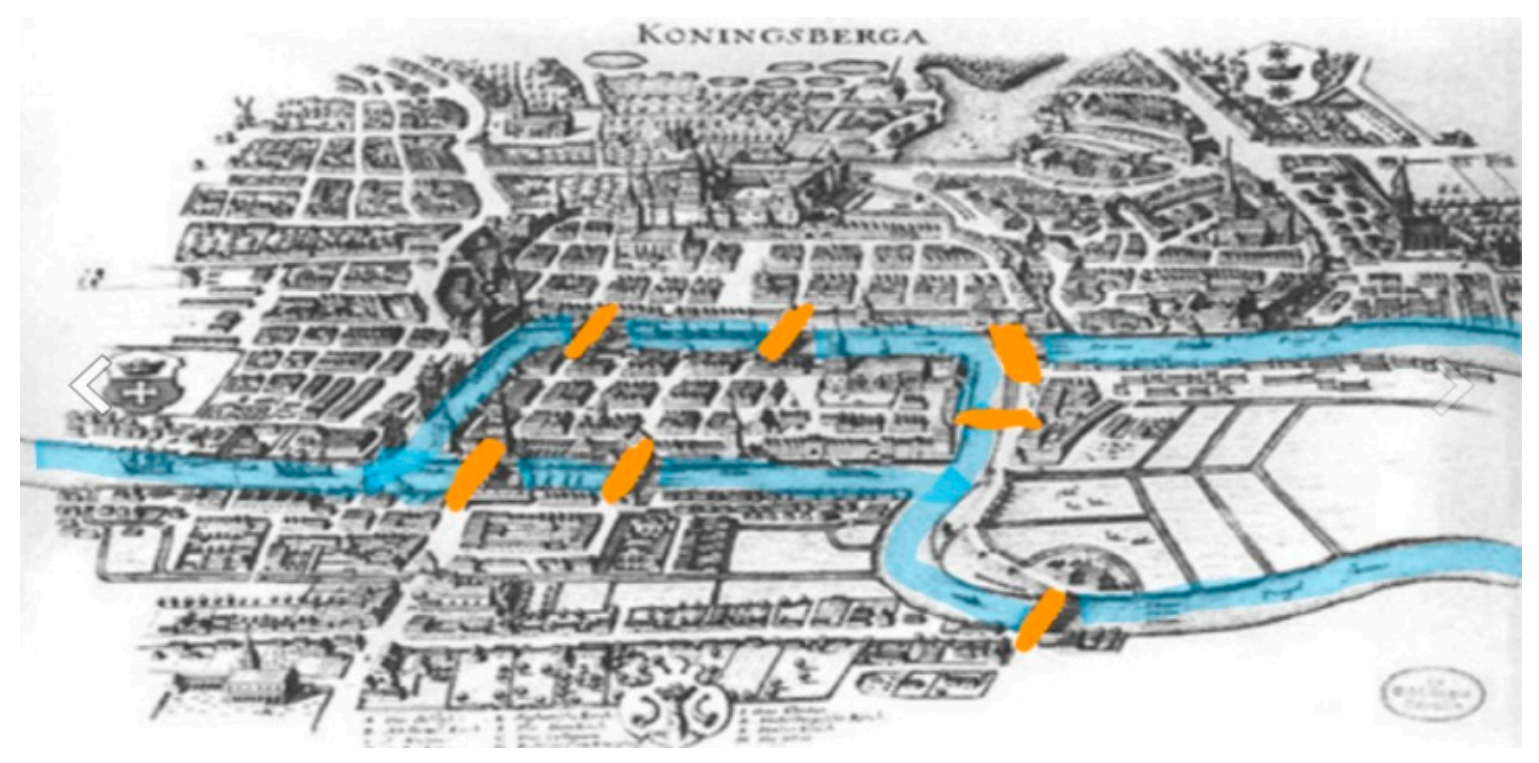

Figure 4. A map of 18th-century Königsberg, with its seven bridges, highlighted [35].

To solve this problem, Euler applied the vertices for the four landmasses and the edges for the seven walking paths. The visualised Euler's proof is presented in Figure 5 below. This proof is the first recorded case of using a graph to solve a mathematical problem. According to Barabási, there are two important implications. First, graph representation makes some problems simpler and more tractable. Second, path existence does not depend on our ingenuity but the graph's properties [36]. Due to such implications, graph theory played a vital role in providing the means of visualisation. 


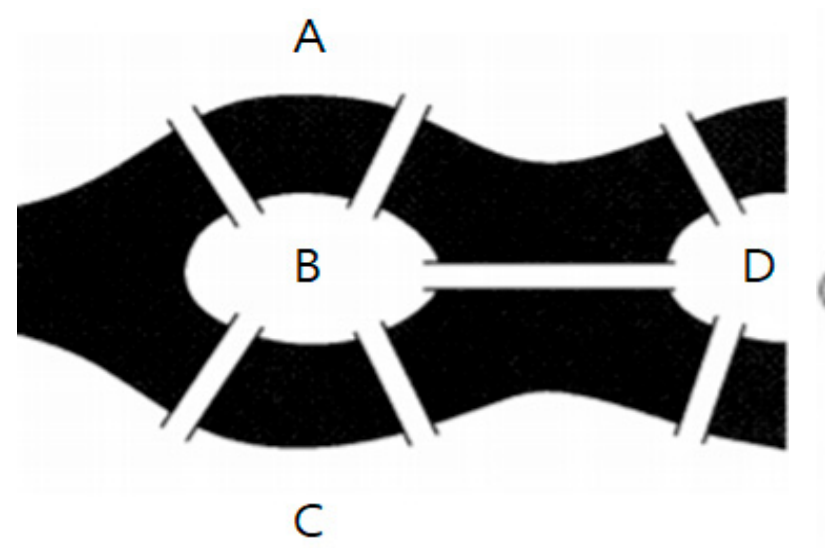

(a)

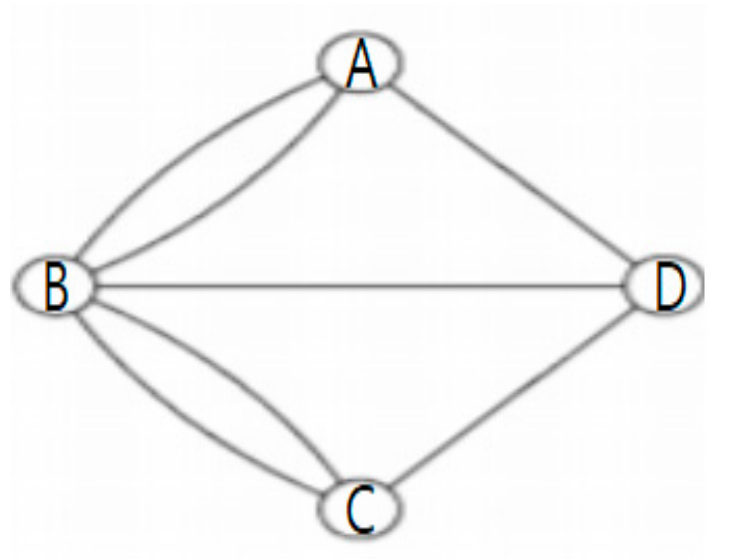

(b)

Figure 5. (a) a simplified depiction of the pattern of the rivers and bridges in the Königsberg bridge problem [35]; (b) the corresponding network of vertices and edges [35].

In addition, graph theory has been applied to the diverse ranges of academic disciplines. These applications were useful when someone wants to explore a complex interrelation in a network format. The most recent application of the graph theory to network analysis is topological data analysis. The most recent study conducted topological data analysis to analyse social media to predict the popularity of images in the data [37]. In addition, their study investigates the feasibility of topological data analysis for social media mining. In addition, their study showed that the shape of data can produce meaningful information [37]. This approach can be useful in analysing visual images in the media, but, as mentioned in the Introduction, our study concerned more about text as a unit of analysis. In this regard, we apply the semantic network analysis in order to discern South Korean conservative and liberal newsmakers' perceptions of PyeongChang 2018. According to de Saussure, understanding text can be formalised as a system of signs [38]. To be more specific, the text consists of a system of multiple subordinate units, such as sentences, phrases or words. A semantic network refers to a group of different words being connected to each other [39]. In this approach, the words can be represented as vertices or nodes. Word relations can be represented as undirected edges [40]. Based on de Saussure's approach, Drieger employed a semantic network model which considers the text as a network of connected words [41]. Based on the theoretical model of the semantic network, this study will explore the word connections from the texts embedded in the conventional news media-leading conservative and liberal newspapers in South Korea.

\subsection{Algorithm of Theoretical Framework}

The study aims at probing how the South Korean conservative and liberal media framed PyeongChang 2018 differently. The problem of this research can be a negative impact resulted by this contrasting news frames from the two types of newspapers. To address this problem, this study employed two theories-framing theory and graph theory. To formulate the theoretical framework, research problem and its further consequences, this study suggests the algorithm in Figure 6.

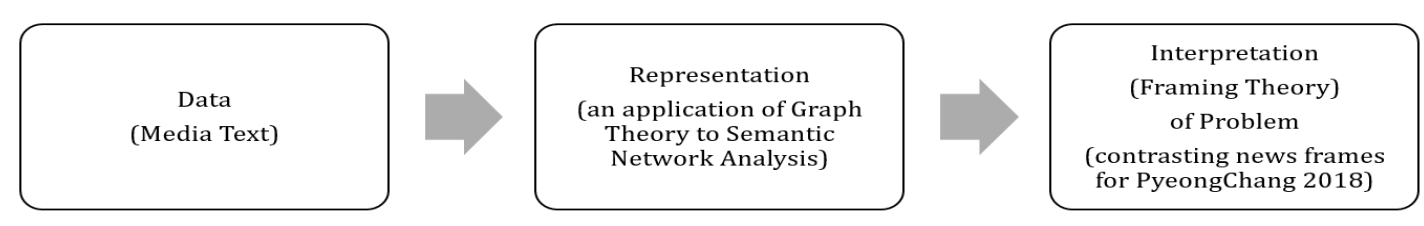

Figure 6. Overview of the proposed framework. 


\section{Methods}

\subsection{Semantic Network Analysis}

Recently, semantic network analysis has been widely accepted as a helpful method exploring word associations in the texts. Semantic network analysis is a form of content analysis that identified the network of associations between concepts expressed in the text $[42,43]$. The core of semantic network analysis is "collecting a small set of texts from 'critical junctures' in the life of 'a social movement for study"' [44] (p. 229). Doerfel and Barnett conducted a semantic network analysis to probe the structure of the International Communication Association (ICA) [45]. They extracted the words from the titles of the papers presented to ICA. Semantic network analysis identifies a new cluster of concepts, so it enables us to explore the meaningful ideas from the texts [43]. Analysing a meaningful cluster of concepts corresponds well with framing analysis. Semantic network analysis addresses the issue saliences mentioned by Entman's study on frames [46].

Since the importance of big data research, automated content analytic methods (such as text mining, natural language processing, knowledge representation network analysis and visual analytics) drew a significant amount of attention [41]. Among these possible options suggested, we focused on automated semantic network analysis focusing on exploring framings. Schultz et al. explored associate frames about the 2010 BP Oil Spill Crisis to explore the interplay of public relations and news in a crisis. They collected a considerable amount of news articles to examine the frame difference between UK and US news items in the BP crisis [47]. Their results contributed to analysing the interplay between public relations and news in crisis situations [47]. Motta and Baden aimed to investigate the dynamic of frames for finding out their evolutionary factors. Their works are useful to overlook the trend of dynamic transformation regarding the forceful discourses, such as emergence, evolution, consolidation or crisis [48]. David et al. examined the associated media framings of the population issue in the Philippines to reveal the strategic framings [49]. Jiang et al. aimed to investigate how American and Chinese media framed the Arab Spring in 2010. Their results presented the competition between the framings of two main global actors with different political, cultural frames [46]. Based on the aforementioned empirical studies, we believe that an application of semantic network analysis is helpful to explore three aspects. The first one is frame difference between conservative and liberal media news items in PyeongChang 2018. This aspect could show how different types of newspapers perceived PyeongChang 2018. The second one is frame dynamics of such framing over the two months of this event. It suggests how these newspapers took either constant or different attitudes to PyeongChang 2018. The third one is strategic frames by these media camps. It reveals that these newspapers' emphasise PyeongChang 2018 in terms of their public relations.

\subsection{Data}

In line with empirical studies, this study conducts automated semantic network analysis by using NodeXL (software for automatic text analysis). The data collection for this study consists of three steps. First, this study selected 'the PyeongChang Winter Olympics' as a keyword for exploring the relevant articles published in conservative and liberal newspapers. Second, this study collected the articles over a set period of time (from January to February 2018) for capturing the moment of most heated debates on PyeongChang 2018. Third, this study conducted a keyword search by employing the search engine in the websites of these newspapers-Chosun Ilbo [50], JoongAng Ilbo [51], The Hankyoreh [52], and The Kyunghyang Shinmun [53]. A total of 445 articles were collected from two conservative newspapers in South Korea (Chosun Ilbo and JoongAng Ilbo), 102 articles from two liberal newspapers in South Korea (The Hankyoreh and The Kyunghyang Shinmun). The summarised overview of the number of collected articles are presented in Table 3. 
Table 3. Overview units of analysis.

\begin{tabular}{ccc}
\hline Political Orientation & Newspapers & Number of Articles \\
\hline \multirow{2}{*}{ Conservative } & Chosun Ilbo & 376 \\
\cline { 2 - 3 } & JoongAng Ilbo & 69 \\
\hline \multirow{2}{*}{ Liberal } & The Hankyoreh & 35 \\
\cline { 2 - 3 } & The Kyunghyang Shinmun & 67 \\
\hline
\end{tabular}

The data analysis of this study consists of three steps. NodeXL was a software for extracting, analysing and visualising the semantic networks from the collected data. First, the collected data were stored by each month as two separate worksheets for the purpose of comparative analysis. Second, this study used 'words and word pairs' option (one of the graph metrics of NodeXL) to work out the vertices and edges of the semantic networks. Finally, NodeXL was employed for the visualisation of the semantic networks.

This study chose four newspapers containing two conservative ones and two liberal ones. The sampling criteria of this study is mainly based on the number of paid circulation, which refers to the number of subscribers. Table 4 shows the number of the circulation number in 2017. For the conservative media, Chosun Ilbo, DongA Ilbo and JoongAng Ilbo were the major three newspapers in South Korea. Among these three, we chose Chosun Ilbo and JoongAng Ilbo due to their availability of the search engines. For the liberal media, The Hankyoreh and The Kyunghyang Shinmun were the two major liberal newspapers.

Table 4. Top ten daily newspapers based on circulation (in 2017) [54].

\begin{tabular}{cccc}
\hline Ranking & Newspaper Names & Paid Circulation & Remarks \\
\hline 1 & Chosun Ilbo & $1,254,297$ & Nationwide Daily Newspaper \\
\hline 2 & DongA Ilbo & 729,414 & Nationwide Daily Newspaper \\
\hline 3 & JoongAng Ilbo & 719,931 & Nationwide Daily Newspaper \\
\hline 4 & The Maeil Business Newspaper & 550,536 & Economic Newspaper \\
\hline 5 & The Korea Economic Daily & 352,999 & Economic Newspaper \\
\hline 6 & $\begin{array}{c}\text { The Nongmin Shinmun } \\
\text { (published three times a week) }\end{array}$ & 287,884 & Newspaper for Farmers \\
\hline 7 & The Hankyoreh & 202,484 & Nationwide Daily Newspaper \\
\hline 8 & The Kyunghyang Shinmun & 165,133 & Nationwide Daily Newspaper \\
\hline 9 & Munhwa Ilbo & 163,090 & Nationwide Daily Newspaper \\
\hline 10 & The Hankook Ilbo & 159,859 & Nationwide Daily Newspaper \\
\hline
\end{tabular}

The research period is from January to February 2018. This study set this period for two reasons. First, PyeongChang 2018 was held from 9-25 February 2018. Second, January 2018 was the preceding month of this event. In South Korea, there has been a number of debates emerged during this month. Figure 7 shows that there has been a sharp increase in terms of the numbers of related-news items published from January 2018. Even though the data collection period can be short, it can be beneficial to capture such heated debates on PyeongChang 2018. 


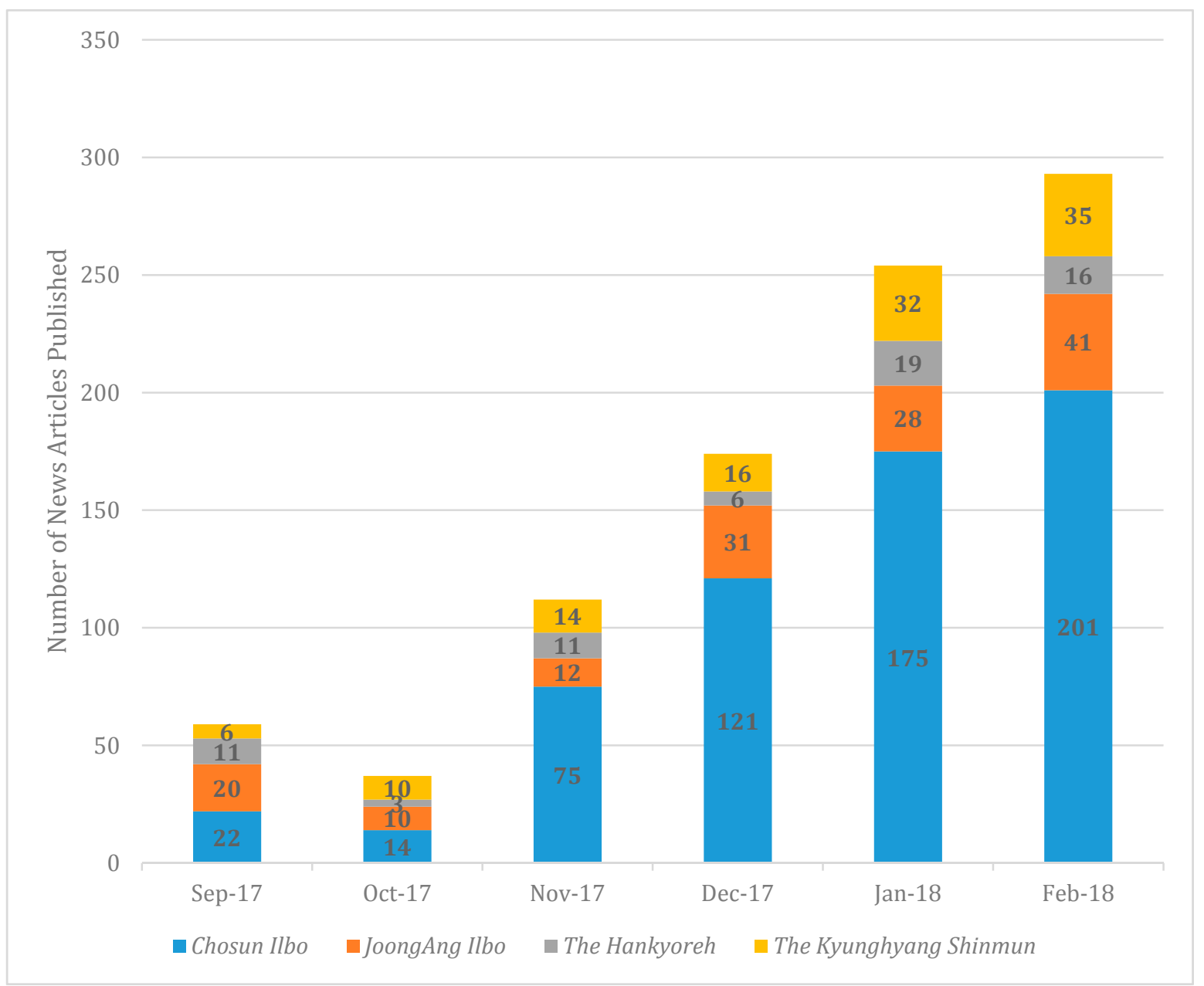

Figure 7. Growth in numbers of media coverage on PyeongChang 2018 from September 2017 to February 2018 (focusing on four selected newspapers).

\section{Results}

First of all, it is useful to look at the number of articles these two groups of newspapers published (Figure 4). In January, a total of 254 articles were released on PyeongChang 2018 (203 by conservative and 51 by liberal media). In February, the Olympic month, a total of 293 articles (15\% more than the previous month) were published (conservative: 242, liberal: 51). Given the quantity of article published (Figure 8), we were able to find out three findings. First, the conservative newspapers' editorials seemed to pay more interests towards PyeongChang 2018 than the liberal ones. Second, the conservative newspapers' editorials seem to have temporarily allocated more resources for covering PyeongChang 2018. Korean newspapers generally have a flexible resource management system to flexibly cover any issues if necessary [55]. In other words, when the agents want to cover a certain issue more, the editorial board invests more resource in reporting PyeongChang 2018. Third, based on their huge circulation (Table 3), the conservative newspapers should have attempted to influence public opinion by approaching the subscribers. 


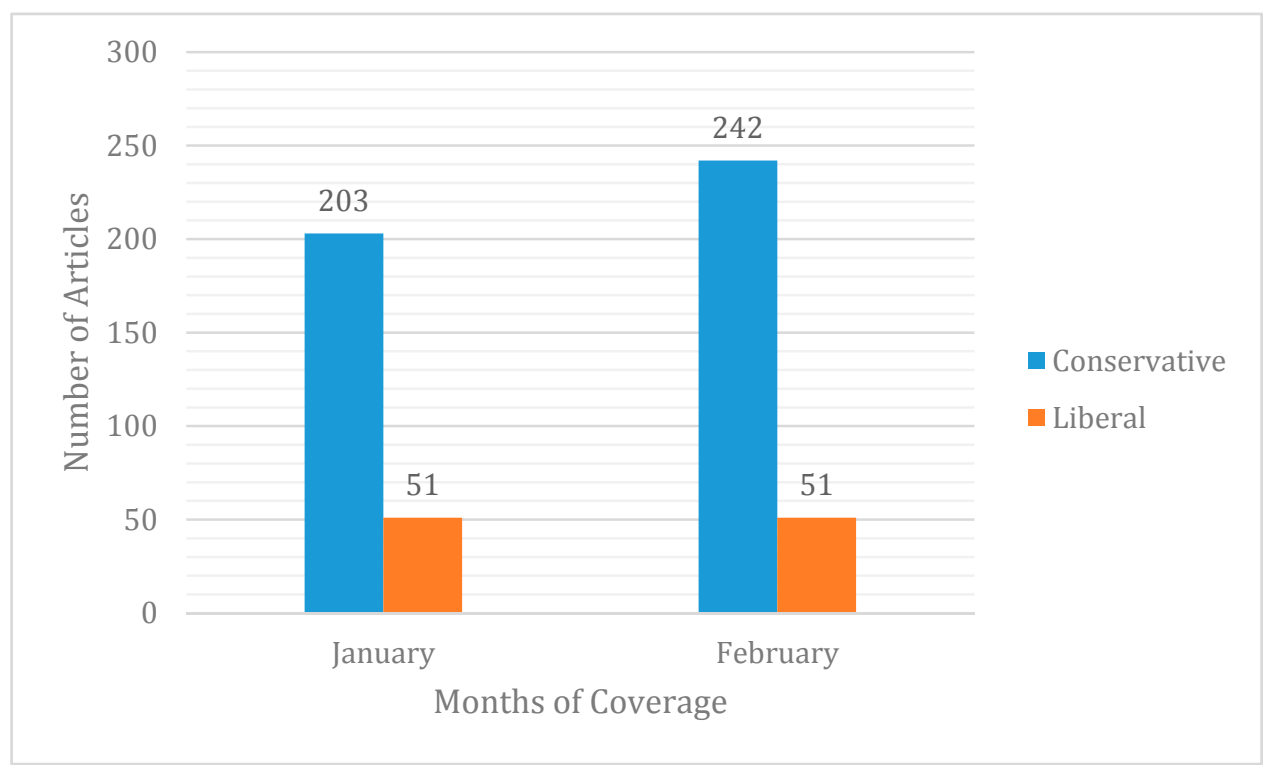

Figure 8. Composition of the articles over the period (January to February 2018).

To compare coverage frequency by period and by newspaper, a weekly publication dynamics was illustrated as in Figure 9. For the conservative newspapers, two peaks were found-the last week of January (24-31 January) and the second week of February (8-14 February). During the period of the first peak, the most news items were dedicated to covering the readiness of PyeongChang 2018 organisation committee, and South Korean athletes' expected results during the Olympics. During the second peak, the newspapers mainly covered the issues of forming a unified Korean female ice hockey team and North Korea's participation in the PyeongChang Olympics. For the liberal newspapers, the second week of February (8-14 February) was the only peak. North Korea's participation in PyeongChang 2018 was the central theme for the coverage during this period.

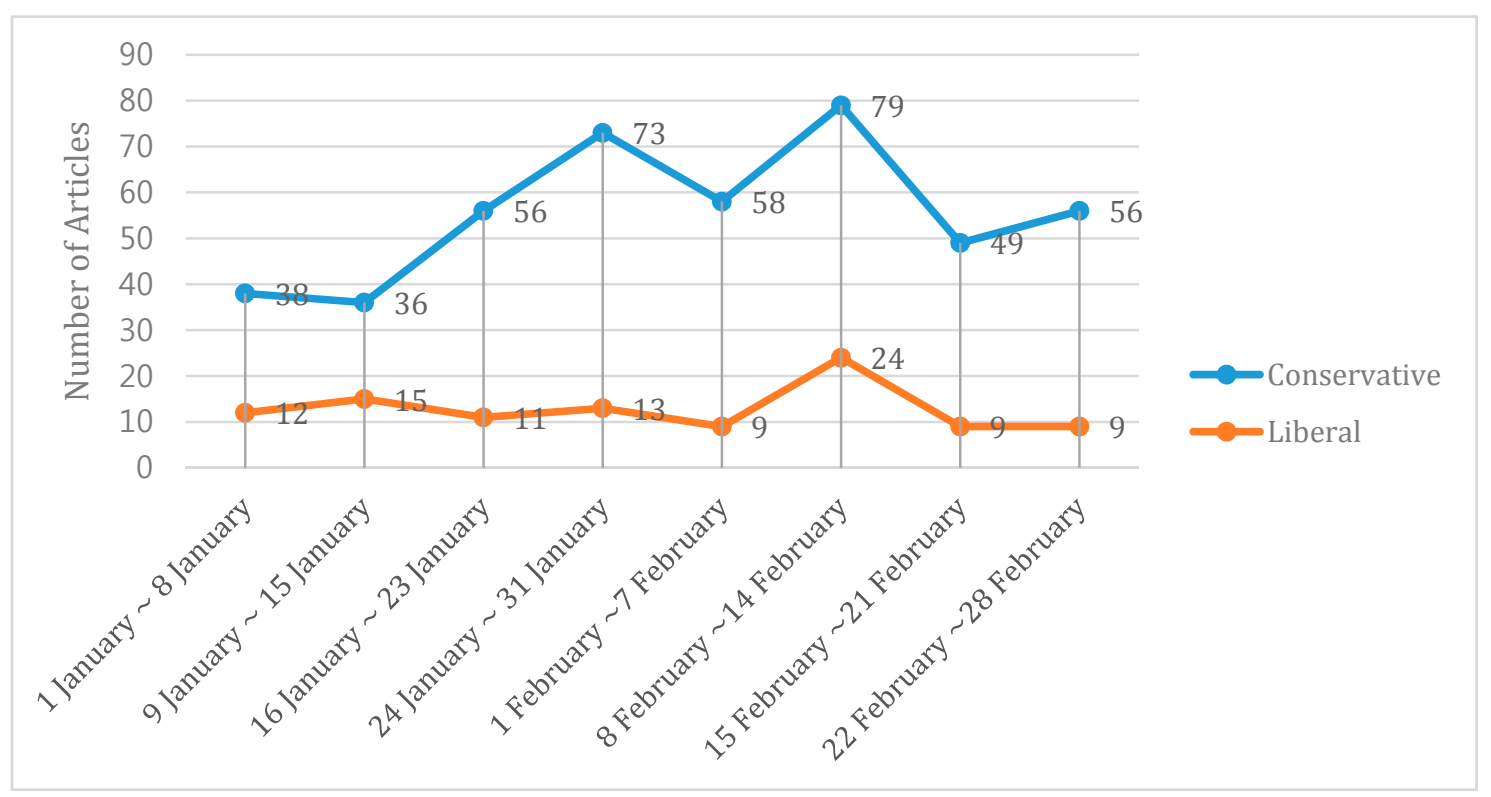

Figure 9. Weekly dynamics of articles published about PyeongChang 2018.

Although two groups of newspapers had the same peak, their responses were different. Looking at the articles' sentiment about PyeongChang 2018 (Figures 10 and 11), each group of newspapers has different evaluations. In Figure 10, conservative newspapers negatively evaluated the PyeongChang 
Olympics. Such a negative sentiment usually becomes evident in the case of covering North Korea's participation in PyeongChang 2018. They viewed North Korea as a violator of peacebuilding of the Korean peninsula. Conversely, liberal newspapers positively evaluated the PyeongChang Olympics. They considered North Korea's participation can be a momentum for peacebuilding of the Korean peninsula. In Figure 11, both conservative and liberal newspapers reduced the articles with either positive or negative sentiments. Newspapers of these groups focused on covering PyeongChang 2018 as an event per se. They covered the achievements of South Korean team's achievements such as medal-winning in the skeleton, short track and speed skating and outstanding achievement in figure skating. From the results of Figures 10 and 11, three implications can be pointed out. First, both conservative and liberal newspapers are more likely to give their positive and negative evaluations regarding the PyeongChang 2018 in January. It means that these newspapers tried to clinch their argument. Second, the conservative newspapers generally employed more negative framings for reporting PyeongChang 2018, and the liberal newspapers did positive framings for reporting the Olympics. Third, the conservative newspapers are more likely to attempt to politicize PyeongChang 2018 in South Korea.

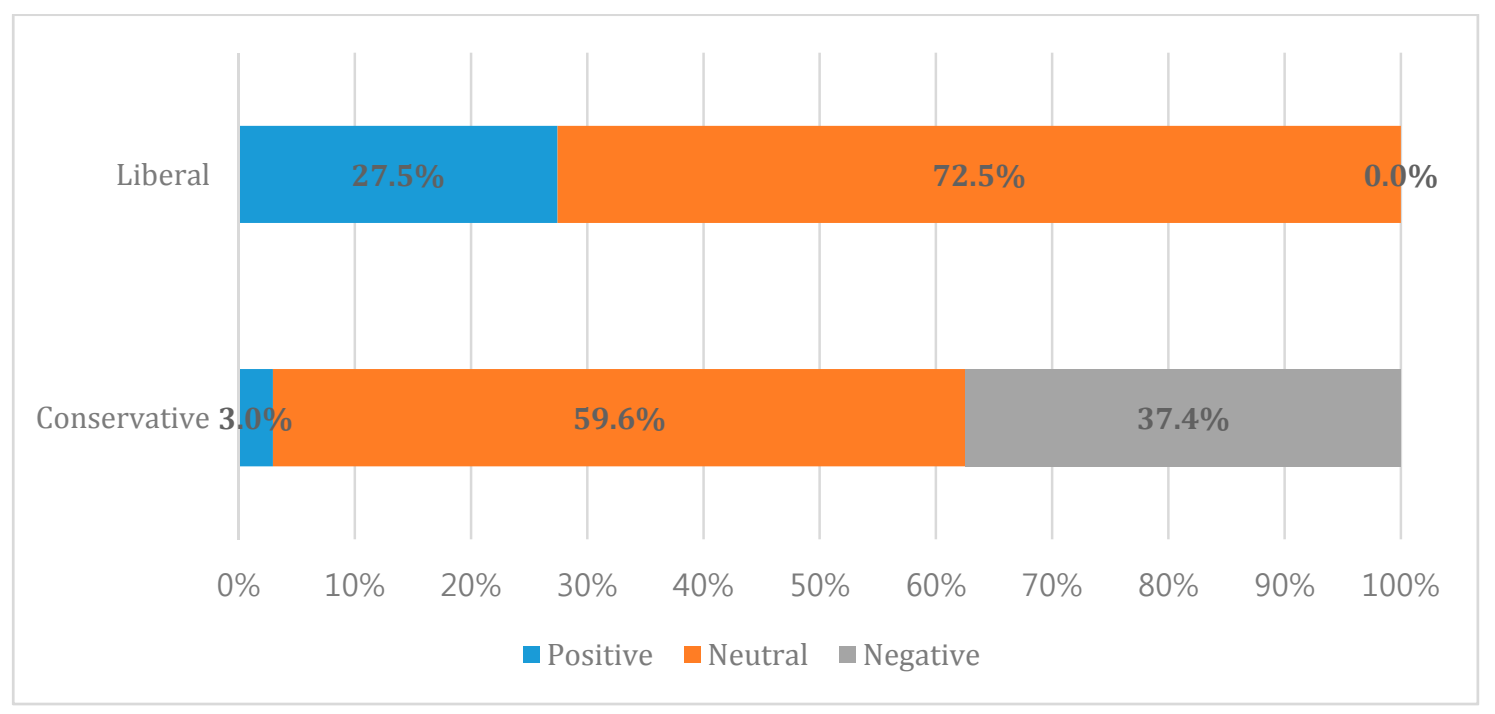

Figure 10. Journalists' evaluations regarding PyeongChang 2018 published in January.

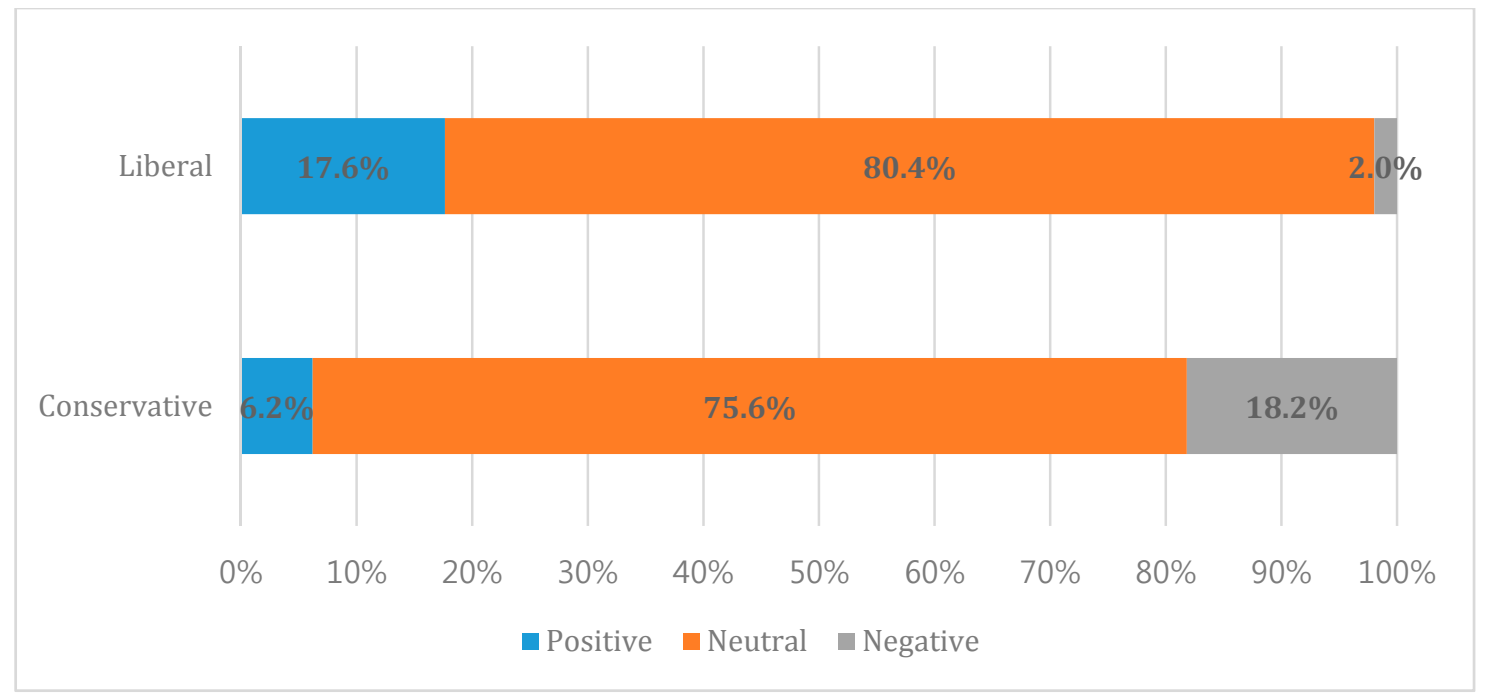

Figure 11. Journalists' evaluations regarding PyeongChang 2018 published in February. 
Figure 12 shows the semantic network of conservative newspapers' media framings, and Figure 13 does that of liberal newspapers in January 2018. Table 4 shows how the betweenness centrality of significant vertices ('keywords') are different between the conservative and the liberal newspapers. The values in the table are significant because they identify the core concepts within their news texts. It means that, when a vertex records a high value in betweenness centrality, this vertex is highly connected to other vertices within the semantic networks. To extend journalist evaluations about PyeongChang 2018, this study employed automated semantic network analysis for presenting salient framings of conservative newspapers and liberal newspapers. With this regard, NodeXL enables this study to visualise the results.

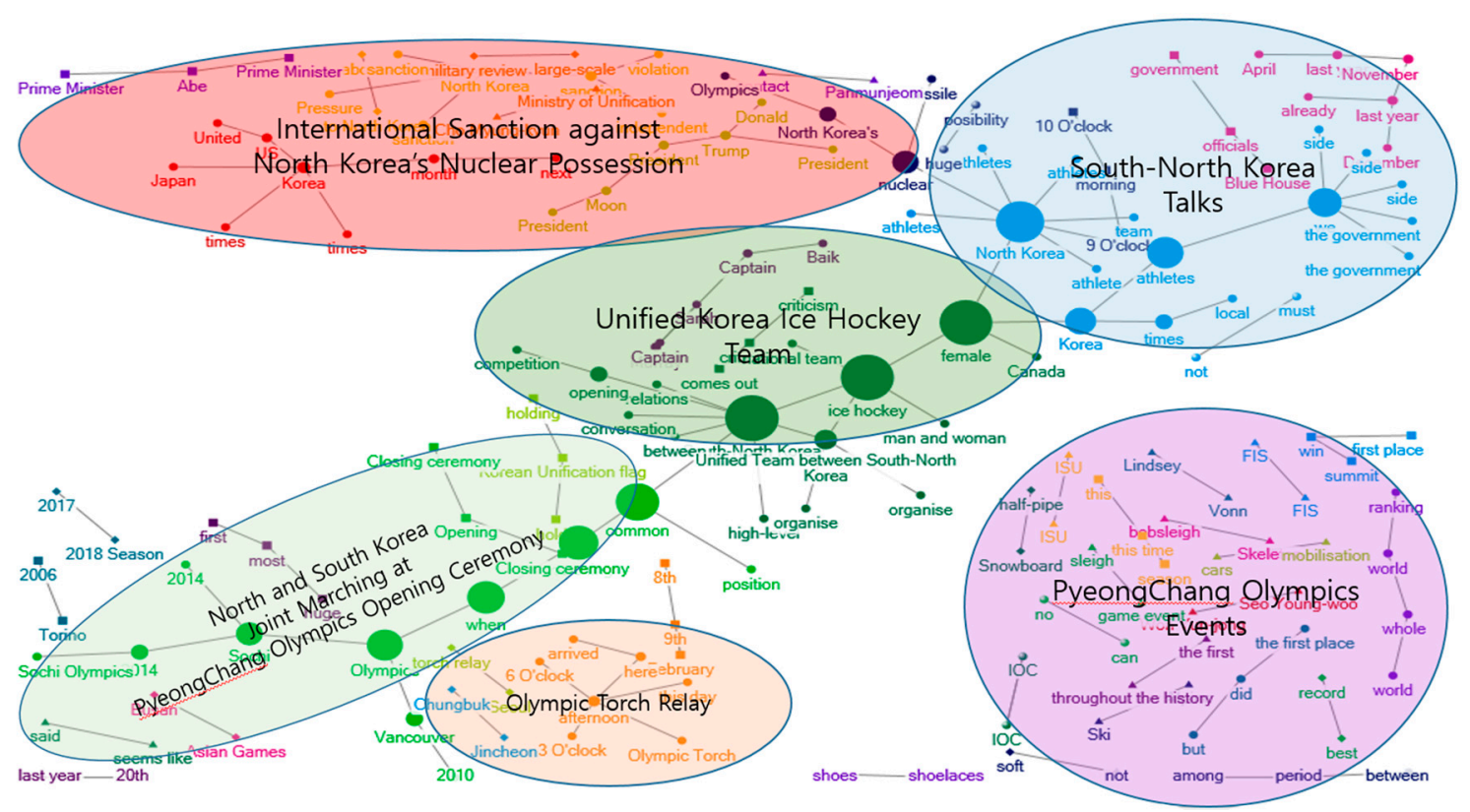

Figure 12. Semantic network of conservative media in January 2018.

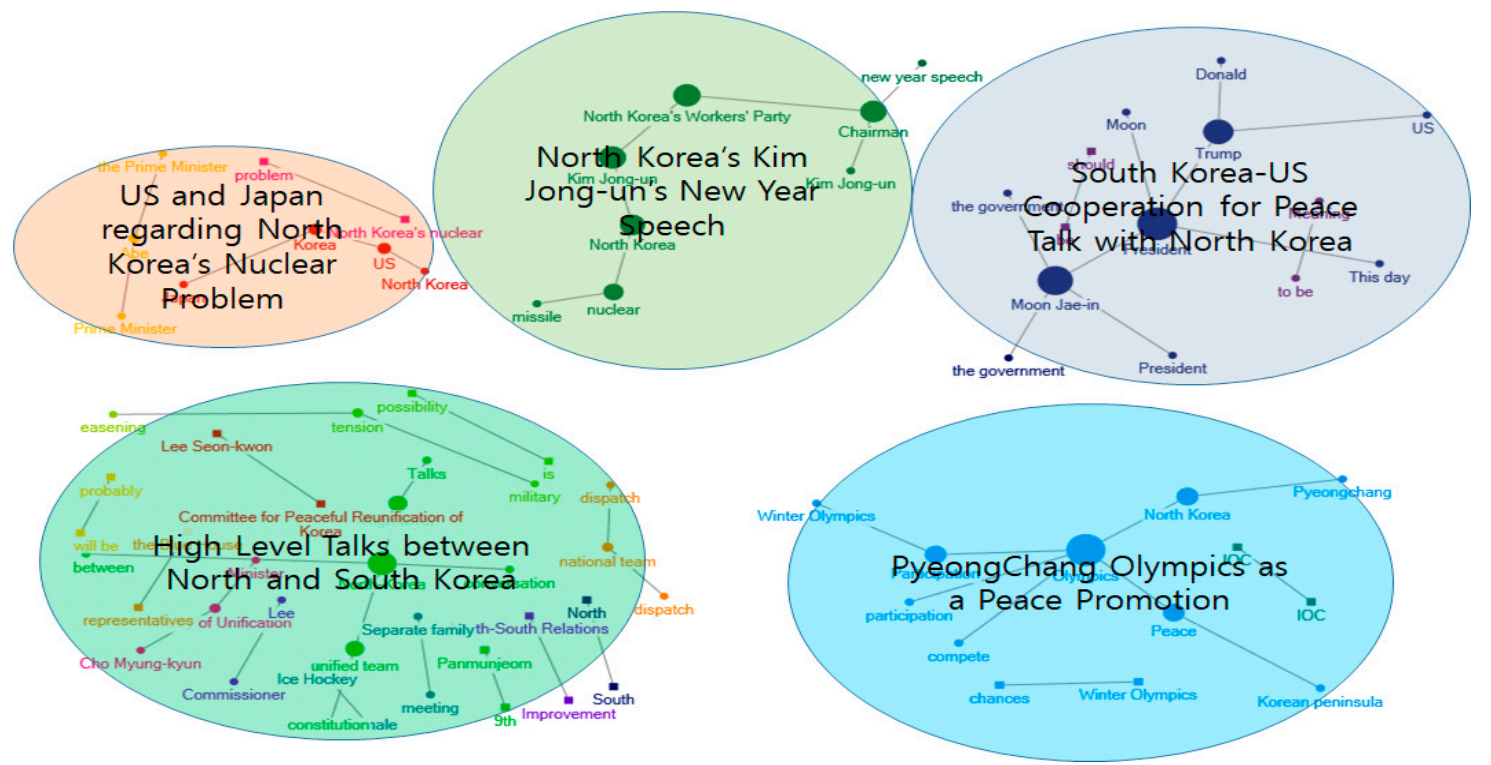

Figure 13. Semantic network of liberal media in January 2018.

In Figure 12, based on the size of vertices, there are four framings are worth further investigation - "international sanction against North Korea's nuclear possession," "South-North Korea talks", "Unified Korea ice hockey team", and "North and South Korea joint marching at PyeongChang 
Olympics opening ceremony." For the first framing, "North Korea" and "nuclear" were two biggest vertices (also presented in Table 4). It means that the conservative newspapers stressed these words when they publish articles connected to this framing. Considering the published articles further, Chosun Ilbo is likely to criticise South Korean liberal government in line with global sanctions against North Korea. For instance, "critics warned South Korea might violate UN resolution regarding North Korea when the South Korean government supports the North Korean athletes and cheering groups participating in the 2018 PyeongChang Olympics" [56]. Another example is "when the South Korean government supports North Korean team's participation, it is highly possible to violate the international sanctions against North Korea [ ... ]. The US government voice concern about the importance of keeping such international sanctions" [57]. For the second framing, "North Korea", "athletes", "(South) Korea" and "(South Korean) government" were emphasised in terms of the size of vertices (also in Table 4). The conservative newspapers tried to convey their putative North Korea's ulterior motives to their readers. For example, "we all know why North Korea suddenly wanted to participate in the PyeongChang Olympics. North Korea wanted to utilise this chance for creating a gap between the South Korean government, who wishes to North-South talks, and the US government, who wished to dismantle North Korea's nuclear weapons" [58]; “North Korea wanted to use North-South talks related with PyeongChang Olympics as one of instruments to achieve its two strategic objectives-'sticking to nuclear violence' and 'overcoming international sanctions' — which were adopted and proclaimed by North Korea's Workers' Party during their New Year's congress" [59]. In the third framing, "North Korea", "ice hockey", and "female" were emphasised in the texts of the conservative media (also in Table 4). Connected to this framing, "common", "closing ceremony", "Olympics" were stressed in the fourth framing (also in Table 4). The conservative newspapers warned a unified Korean ice hockey team and North-South Korea joint marching can mar South Korea's national identity and legitimacy. Chosun Ilbo pointed out Korean unification flag replaced Taegeukgi (the flag of South Korea) at the opening ceremony of PyeongChang 2018. For example, "North and South Koreas will establish a unified Korean ice hockey team and joint marching at the opening ceremony [ ... ]. The South Korean government said 'we might hold Korean unification flag' at the ceremony [ ... ]. This means we will not be able to use the Republic of Korea during the ceremony [ ... ]. This is unacceptable" [60].

In Figure 13, four framings are worth further investigation- “North Korea's Kim Jong-un's News Year Speech", "South Korea-US cooperation for peace talk with North Korea", "high level talks between North and South Korea", and "PyeongChang Olympics as a peace promotion". In the first framing, the liberal newspapers attempt to check out possibility of North-South Korea relations improvement. "North Korea's Workers' Party", "North Korea", and "Kim Jong-un" were the key words within this framing (also in Table 4). From the articles in the liberal newspapers, these keywords were used to address the North Korea's willingness to talk with its international counterparts. In the related article by The Hankyoreh, "Chairman Kim Jong-un mentioned the chance of North Korea's participation to PyeongChang 2018 in his New Year speech [ ... ]. Regarding the possibility of North-South talks, there were some mixed reactions to his speech [ ... ]. The Minjoo Party of Korea, the ruling party, optimistically viewed his speech as a further peace movement [ ... ]. The Liberty Korean party, the opposition party, interpreted his speech as North Korea's two-facedness [61]." The Hankyoreh assessed practicality of North Korea's sending a delegation over to PyeongChang 2018 [62]. In the second framing, "Moon Jae-in", and "Trump" were the keywords (in Table 4). The liberal newspapers addressed that South Korean and the US leaders showed the supportive attitudes towards North-South talks after PyeongChang Olympics. US President Trump mentioned that "(he) supports the North-South talks, over the phone [ ... ] Within the US, some pointed out North Korea's willingness to talk could be its camouflage of peace promotion [ ... ]. However, the US should establish a momentum for the talks with North Korea by utilising this situation wisely. The aim of Trump administration's sanctions against North Korea is its denuclearisation. In order to achieve such objective, they should sit at the negotiation table [63]." In the third framing, the liberal newspapers 
suggested the implication of North-South high level talks as an improvement of inter-Korean relations. For example, North-South high level talks was the opportunity to suggest an implication of their thawing relations [64]. In the fourth framing, "Olympics", "participation", and "peace" were main vertices. In this regard, the liberal newspapers underscored the South Korean government's effort of using PyeongChang 2018 as a peace promotion of the Korean peninsula. For instance, the South Korean government has emphasized the peace promotion of the Korean peninsula by North Korea's participation in PyeongChang 2018. [65] Kim Hyun, the spokesman of the Minjoo Party of Korea, mentioned that "Moon Jae-in administration's effort to turn PyeongChang 2018 into peace Olympics is complying with the Special Act on PyeongChang Olympics [ . . . ]" [66]. Park Joo-sun, the Second Deputy Speaker of the National Assembly, asserted that "any trials to make PyeongChang 2018 as a political battle should be stopped" [66].

Revisiting Figures 12 and 13 and Table 5, three contrasting points between the conservative and liberal newspapers were found. First, these newspapers showed contrasting interpretation around North Korea's participation in PyeongChang 2018. On the one hand, the conservative newspapers perceived North Korea's participation as an illegitimate issue. On the other hand, the liberal newspapers did the participation as an implication for further peace promotion. Second, these newspapers showed the contrasting expectation to North Korea. The conservative newspapers viewed North Korea's changes with scepticism. On the contrary, the liberal newspapers cautiously suggested the possible change of North Korea regarding its peace promoting efforts in the Korean peninsula. Finally, these newspapers had opposing understanding regard prerequisite to the peacebuilding of the Korean peninsula. The conservative newspapers perceived North Korea's disestablishment of nuclear weapons as an ultimate precondition. The liberal ones perceived talks with North Korea as an effective way of promoting peace in the Korean peninsula.

Table 5. Comparison between Top 20 Vertices by betweenness centrality in January 2018.

\begin{tabular}{cccc}
\hline \multicolumn{2}{c}{ Conservative } & & Liberal \\
\hline Top Vertices & Betweenness Centrality & Top Vertices & Betweenness Centrality \\
\hline North and South Korea & 556 & (South Korean) President & 27 \\
Ice Hockey & 549 & Olympics & 25 \\
Female & 539 & Moon Jae-in & 21 \\
North Korea & 445 & Trump & 15 \\
Unification & 359 & North and South Korea & 13 \\
Entrance & 296 & (North Korean) Workers' Party & 12 \\
Moment & 266 & Kim Jong-un & 12 \\
Athletes & 249 & Chairman & 11 \\
Competition & 242 & North Korea & 10 \\
We & 210 & Peace & 7 \\
Korea & 177 & Participation & 7 \\
Nuclear & 128 & North Korea's & 7 \\
Sochi & 128 & Nuclear & 6 \\
Unified Team & 87 & Unified Team & 5 \\
Held & 44 & High-level Talks & 5 \\
Vancouver & 44 & South Korea & 2 \\
2014 & 44 & The US & 2 \\
North Korea & 44 & Tension & 1 \\
Perspective & 44 & Korean) Representatives & 1 \\
One & 19 & (South Kouth Korean) Ministry of Unification & 1 \\
\hline
\end{tabular}

In Figure 14, the framings related to North Korea were salient in the texts of the conservative newspapers. They mainly addressed the events of PyeongChang 2018-South Korean female curling team and unified Korean female ice hockey team. Table 5 indicates that "female curling team" bears the high value of betweenness centrality in the conservative newspapers. In Figure 11, we were able to find out liberal newspapers focused on covering the PyeongChang 2018 as a peace-promotion event. Table 5 shows that "ice hockey team" bears the high value of betweenness centrality in the liberal newspapers. 


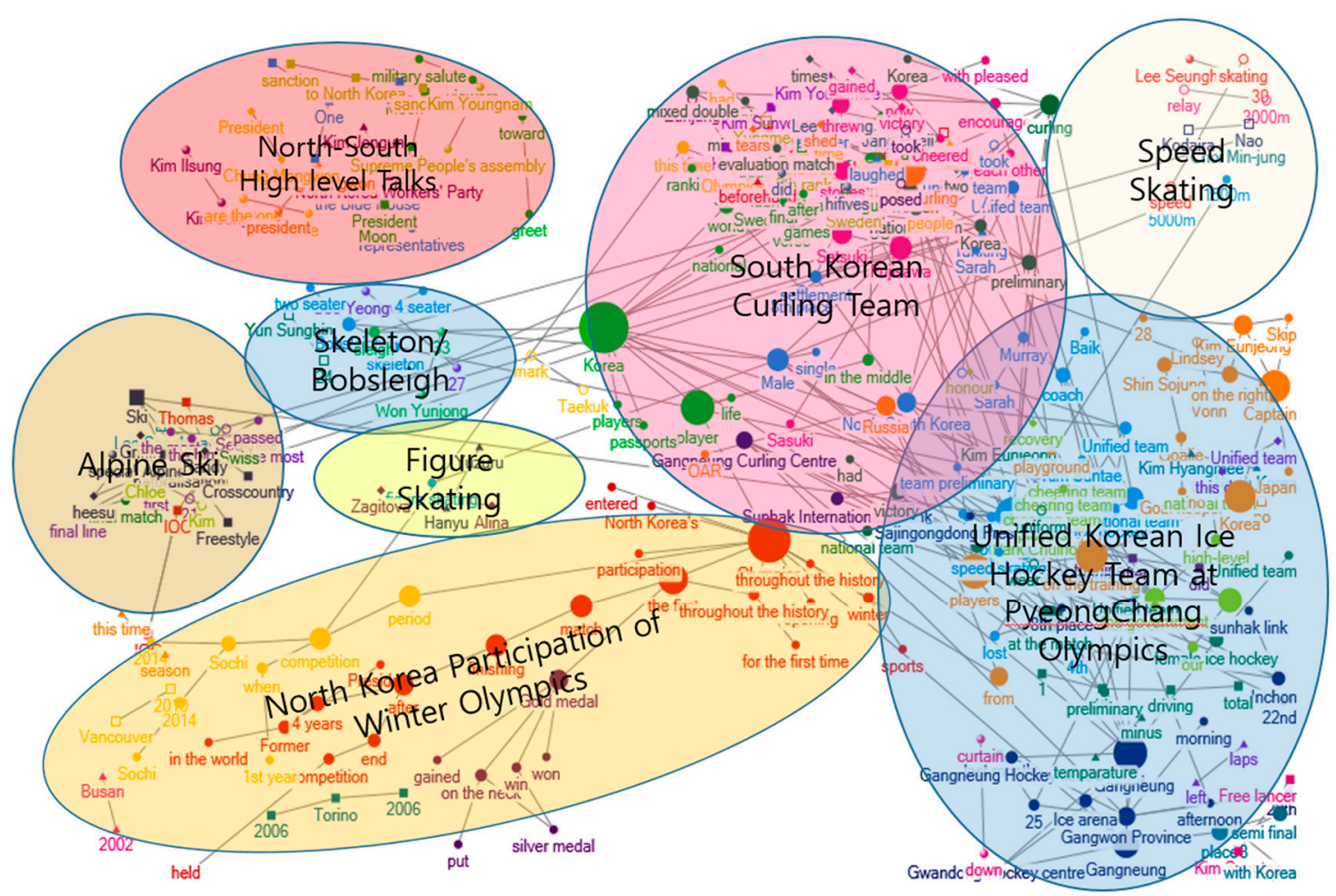

Figure 14. Semantic network of conservative media in February 2018.

From Figure 14 and Table 6, the conservative newspapers employed the words (vertices) related to the South Korean team's achievement such as "victory", "pleased", "laughed", and "cheered". In addition, they employed negative words such as "lost" and "minus" when they cover the issues about unified female ice hockey team (Figures 14 and 15 and Table 6). Other than these events, the conservative newspapers paid their attention to cover South Korean teams in other games such as alpine ski, figure skating, speed skating and skeleton/bobsleigh. They employed the wordings of their achievements such as "gold medal", and "silver medal" (Figure 14 and Table 6). In Figure 14 and Table 5, the conservative newspapers were likely to emphasise South Korean teams' achievements in PyeongChang 2018 rather than a unified Korean ice hockey team. From Figure 15 and Table 5, the liberal newspapers focused on covering unified female ice hockey team and North Korea's Samjiyon Orchestra's performance in South Korea during PyeongChang 2018. Considering other minor framings, the liberal newspapers covered the articles on South Korean team at the Olympics, Russia's participation in the name of OAR (Olympic Athletes from Russia), a novel related to PyeongChang 2018 (Happy Days of Grump, written by a Finnish writer Tuomas Kyro) and the investigations into Woo Byung-woo's (a senior presidential secretary during the ousted Park's government) dispatching a spy to Kim Jin-sun (the former chief of the PyeongChang Winter Olympics Organising Committee). 
Table 6. Comparison between Top 20 words by betweenness centrality in February 2018.

\begin{tabular}{cccc}
\hline \multicolumn{2}{c}{ Conservative } & & \multicolumn{2}{c}{ Liberal } \\
\hline Top Vertices & Betweenness Centrality & Top Vertices & Betweenness Centrality \\
\hline Korea & 8888.6829 & Held & 29 \\
Olympic Games & 6428.7636 & Saimdang Hall & 25 \\
Female & 4203.9763 & Gangneung Art Centre & 24 \\
Athletes & 4074.0719 & Gangwon Province & 21 \\
Of athletes & 3749.5833 & Female & 17 \\
During the training & 3380 & Afternoon & 16 \\
Female curling & 3374.2258 & Ice Hockey & 10 \\
Held & 3351.7491 & 8th of February & 9 \\
South Korea's & 3230 & At Ice Arena & 9 \\
Claim & 3165 & An Eccentric Main & 6 \\
The first & 2994 & Former & 6 \\
At the competition & 2118.7878 & Pence (US Vice President) & 6 \\
Gangneung & 2007.9263 & North and South Korea & 6 \\
Players & 1966.9673 & Single Skating & 6 \\
Fujisawa & 1628 & Old man & 6 \\
Competitions & 1620 & Grump & 4 \\
Male & 1616.4879 & Whole & 4 \\
Match & 1561.5119 & 1448 & 2 \\
Completed & 1438.7903 & Winter Olympics & 2 \\
South Koan National Team & Short Track & Past \\
\hline
\end{tabular}

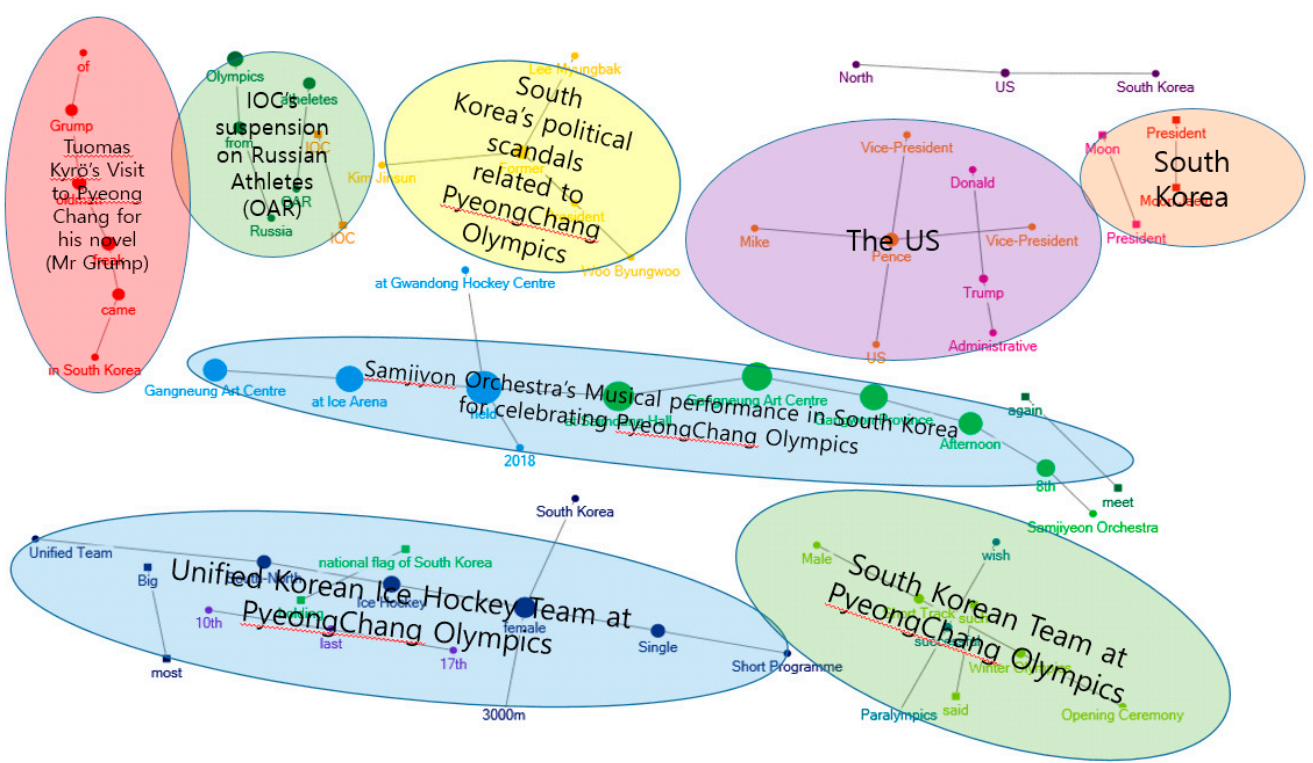

Figure 15. Semantic network of liberal media in February 2018.

Overviewing the salient framings formed by two different newspaper camps, we were able to find out three findings. First, the conservative newspapers evaluated the PyeongChang Olympics as a negative event while the liberal newspapers did oppositely. Second, the conservative newspapers featured more diverse framings about the South Korean team's achievements than the liberal ones. Third, the conservative newspapers were more resourceful than the liberal ones regarding particular emphasis on the framings. Arguably, based on these findings, the readers are more likely to accept the framings from conservative media. If the framings of the conservative newspapers influenced the South Korean public, they would evaluate the PyeongChang Olympics in a negative way (such as giving negative outlooks or assessments). To check this claim, some of Korea Gallup's weekly public opinion surveys on the public's outlooks and assessments about the PyeongChang Olympics would be helpful references. For the surveys, Korea Gallup hosted 1000 respondents each by conducting Random-Digit Dialing (RDD) surveys. According to the results of these surveys conducted before and after the PyeongChang Olympics, 73\% of the respondents expected that the PyeongChang Olympics would be successfully held, and $84 \%$ of the respondents evaluated that the Olympics were successfully 
held [67]. After considering these results, we were able to find out that the conservative newspapers were not successful in influencing upon the public opinion about the Olympics. Korea Gallup also asked two questions before and after the event regarding North-South Korean joint marching and forming a North-South Korean unified female ice hockey team. However, before the Olympics, $53 \%$ of respondents perceived North-South Korean joint entrance was a valuable event for the Korean peninsula, $68 \%$ of the respondents evaluated this joint entrance optimistically after the Olympics. However, forming a North-South Korea unified female ice hockey team was evaluated somewhat negatively (50\%) than positively $(40 \%)$ before the Olympics. After the Olympics, however, this trend was overturned. Fifty percent of the respondents gave a positive evaluation, and $36 \%$ of the respondents gave a negative evaluation [67]. In the next section, we discuss more thoroughly on these contrasting results.

\section{Discussion}

This paper is now addressing our research questions and testing the hypotheses. For the first research question $(\mathrm{Q} 1)$, different attitudes of conservative and liberal media from their evaluations towards the PyeongChang Olympics were found. As in Table 2, the current South Korean government has a compatible relationship with liberal media. Figures 10 and 11 support that the conservative media were inclined to show more unfavourable attitudes towards the government's performance of PyeongChang 2018. With this regard, the results prove that the first hypothesis (H1) is met. Echoing to the empirical studies on press partisanship, the conservative newspapers presented their resistance towards the current liberal government. By addressing the framing theory, each camp of newspapers had contrasting perspectives in framing their news agenda. Figure 12 shows that the conservative newspapers used the framing of "international sanctions against North Korea's nuclear possessions" in describing North Korea. Chosun Ilbo, in particular, showed more explicitly negative attitudes towards the South Korean government's invitation of North Korean officials and athletes to the PyeongChang Olympics. On the contrary, the liberal newspapers covered the PyeongChang Olympics positively. Figure 13 shows that the liberal newspapers used the framing of "Peace Promotion" to depict the Olympics.

For the second research question $(\mathrm{Q} 2)$, this paper attempted to argue which type of newspapers were successfully delivering their messages to the Korean public. The second hypothesis was that conservative media would have been more successful in influencing the public opinion (H2). Comparing our data of media framing and Korea Gallup's public opinion surveys, the conservative newspapers failed to convey their messages to their audiences. The conservative newspapers covered more articles about PyeongChang Olympics, and their journalists employed more diverse framings and more effective words for their readers. In other words, the conservative media were more resourceful than the liberal media. However, the public opinion rejected the conservative media's salient issues and framings. Such resistance shows that our second hypothesis did not meet.

Our third research question $(\mathrm{Q} 3)$ addressed how the public's attitudes were formed. According to the Korea Gallup's public opinion surveys on PyeongChang 2018, the public opinion was compatible with the liberal newspapers' attitudes towards PyeongChang 2018. Both the liberal newspapers and the South Korean public perceived PyeongChang 2018 as a peace promotion event, and they consider this event will contribute to peacebuilding process between North and South Koreas. This finding implies that the South Korean public would be more supportive to the current government. Considering the former President Park Geun-hye's impeachment, the general public has been disappointed with the conservative government. Korea Gallup conducted a public opinion survey on South Korean presidents' job performances. At the end of Park Geun-hye's term, $80 \%$ of the respondents evaluated her performance negatively. After her impeachment, $81 \%$ of the respondents evaluated positively about the following President Moon Jae-in's administration [67]. Since President Park's impeachment, the conservative parties seemed to have lost their public support and legitimacy in South Korean politics. In addition, the Korean public does not accept the information released by the conservative 
newspapers as much as they did before. Thus, our third hypothesis (H3) did not meet. Subsequently, it was expected that the conservative newspapers will continuously employ diverse ranges of framings and anti-government news coverage based on their resources for regaining their influence upon the public opinion.

In this study, the main point of argument was why the South Korean public perceptions are in the same line with the liberal newspapers' framings about PyeongChang 2018 (Q4). The conservative newspapers seem to be negligent in maintaining fair reporting attitudes. Rather, they attempt to bring their readers into the conflictual situations by building anti-North Korean sentiments. The media's core functions include monitoring the social environment, forming the public opinion and strengthening social norms [68]. In covering issues, media should maintain accurate, balanced and neutral reporting attitudes, so that they could establish a forum for public consensus [69]. The Korean public's support for the conservative government and media were significantly diminished. For the past few years, as the public has been disappointed with the wrongdoings of the conservative governments and the conservative media's overlooking attitudes to them. Our last hypothesis (H4) did not meet in this respect. The discordance between the conservative newspapers' framings and the South Korean public perceptions on PyeongChang 2018 imply that the readers proactively examine the genuineness of the news items before accepting the information from the news media.

\section{Conclusions}

This study emphasised that the public does not indiscriminately accept the messages from the media. In other words, the media cannot exercise their influence over their readers as much as they did before. This is not unrelated to the change in the media environment. Above all, the advent of the Internet brings us an emergence of convergence media, which transcends a simple merge of different types of media [70,71], and a new level media device that puts all types of media contents and broadcasting environment together [72] (p. 98). Such trend successfully led to the change of the general public. By using social media, a new communication network has been formed. It means that the public do not merely consume their messages and information from the media and the elites, but produce their discourses with other members of the society as part of a 'multitude' [73] (p. 52). The concept of the multitude, which came from Hardt and Negri's works, can be distinguished from 'masses', 'people', 'mob' and 'class' [74,75]. In other words, the multitude is not depicted as 'people' (which refers to someone challenges the sovereignty authority of the state) nor 'masses' (which refers to indiscriminate or uniform beings) but as a group of main agents who have diversity and distinctiveness. As they argued, the multitudes could be depicted as an image of the open and expandable network, which embraces the diverse ranges of expressions from the members of the society [73] (p. 54) [74,75].

Wellman and Morley explained the characteristics of the multitude by using the term of 'individualised mass' $[76,77]$. The multitudes can exist both as a group of independent individuals and a collective gathering [72] (p. 110). Although the multitudes do not collectively exist as the masses, they showed their strong interests to lead and improve the public opinion regarding social issues. Since the emergence of the individual media, their progressive tendencies are becoming more salient. In addition to the emergence of media convergence, the types of media services and recipients should be considered as well in order to understand the individualisation of the multitude's media-related activities [76,77].

Furthermore, interestingly, their 'individualised' behaviour in social communication enables the emergence of 'collective intelligence.' The collective intelligence is a concept specified by Pierre Levy [78]. He mentioned that the collective intelligence is universally distributed intelligence which can be occasionally improved, coordinated in real time, and mobilised effectively. He subsequently claimed that the current knowledge space could be formed due to the convergence of the Internet and the collective intelligence [78]. He summarised the collective intelligence in the following one sentence "no one knows everything, everyone knows something, all knowledge resides in humanity", and emphasised the starting point and final destination of the collective intelligence are 'mutual 
recognition' [78] (p. 20). In other words, "knowledge is simply the sum of what we know" [78] (p. 13). Furthermore, the collective intelligence is established in forms of a group of thoughts from the individual intelligence and collective knowledge, so it can be an appropriate way of solving the complicated problems of the modern society [78] (pp. 55-56). In addition, such collective intelligence can be realised in the form of diverse ranges of social media such as Facebook, Twitter, YouTube and of individual Internet-based broadcasters like a podcast.

Over the last nine years of the conservative power in South Korea, the collective intelligence has detected and substantiated not a few corruptions and scandals of the former conservative governments. Recently, this discovery was developed into the candlelight revolution and led to an unexpected and unprecedented regime change in South Korea. In light of Jenkin's account, the candlelight revolution can be interpreted as an impactful event which shows that the collective intelligence caused the change in the society [71]. In addition, this event can be interpreted as an evolution of communication structure, which led to social change [71]. As such, the conventional media should pay more attention to the sudden change of media environment and the evolution of the general public. Consequently, the South Korean media environment is facing the issue of maintaining its sustainability in terms of assuring the quality of being able to continue to exist as a reliable source of information. If conventional media neglect their roles supporting media sustainability, South Korean media ecology will face its further degeneration. Therefore, establishing a more sustainable media ecology will be an important prerequisite task for the South Korean society.

Author Contributions: S.-W.Y. conceptualised the theme of the paper and wrote the introduction, the literature review and conclusions of the paper. S.W.C. composed the theoretical framework, results and discussion section. He collected the data, designed the methodology of the article and undertook the analysis of using the software. Both authors contributed equally regarding preparation of the manuscript.

Funding: This research received no external funding.

Conflicts of Interest: The authors declare no conflict of interest.

\section{References}

1. Van Attelveldt, W. Introduction. In Semantic Network Analysis: Techniques for Extracting, Representing and Querying Media Content; BookSurge Publishing: North Charleston, SC, USA, 2008; ISBN 1439211361.

2. Kim, H.-T. A Study on the Strategy and SWOT Analysis of Hosting the 2018 Pyeongchang Winter Olympic Games. J. Korea Entertain. Ind. Assoc. 2011, 5, 14-24. (In Korean) [CrossRef]

3. Lee, S.-D.; Ji, W.-S.; Lee, S.; Park, S.-Y. Inter-Regional Development Projects for the Co-prosperity of Gyeonggi-Do and Gangwon-Do on the 2018 PyeongChang Winter Olympic Game, Gyeonggi Research Institute, Policy Research Series 2011-66. Available online: http://www.gri.re.kr/\%EC\%97\%B0\%EA\% B5\%AC\%EB\%B3\%B4\%EA\%B3\%A0\%EC\%84\%9C / ?brno=3838\&prno=3242 (accessed on 21 October 2018). (In Korean)

4. Ryu, J.-H. 2018 PyeongChang Olympic Games and Regional Development Issues. Korea Tour. Policy. 2011, 45. Korea Culture \& Tourism Institute. Available online: http:/ / www.dbpia.co.kr/Journal/ArticleDetail/ NODE01921445\# (accessed on 21 October 2018). (In Korean)

5. Ahn, D. A Contemplation for the Success of 2018 PyeongChang Olympics. Korea Tour. Policy 2011, 45. Available online: http://www.dbpia.co.kr/Journal/ArticleDetail/NODE01921444 (accessed on 21 October 2018). (In Korean)

6. Cha, M. A Study on the Successful Hosting of the PyeongChang Winter Olympics through Regional Networking and Cooperation. Plan. Policy 2011, 362, 14-21. (In Korean)

7. Yeom, D. The Effect of Intention of the Local Residents for Cooperation for the 2018 Pyeongchang Winter Olympics on Regional Development and Sport Culture. J. Korean Soc. Wellness 2016, 11, 1-12. (In Korean) [CrossRef]

8. Kim, L.; Kim, N. Connecting Opinion, Belief and Value: Semantic Network Analysis of a UK Public Survey on Embryonic Stem Cell Research. J. Sci. Commun. 2015, 14. Available online: https:/ /jcom.sissa.it/sites / default/files/documents/JCOM_1401_2015_A01.pdf (accessed on 19 October 2018). 
9. Kim, Y. Political Orientation of Korean Media and the Crisis in Social Communication. In Communication Crisis in the Korean Society; Korean Society for Journalism and Communication Studies, Ed.; Communication Books: Seoul, Korea, 2001; pp. 170-217. ISBN 9788964061862. (In Korean)

10. Kahn, K.; Kenney, P. The Slant of the News: How Editorial Endorsements Influence Campaign Coverage and Citizens' Views of Candidates. Am. Political Sci. Rev. 2002, 96, 381-394. [CrossRef]

11. Shoemaker, P.; Reese, S. Mediating the Messages: Theories of Influences on Mass Media Content, 2nd ed.; Longman Publication: New York, NY, USA, 1996; ISBN 0801312515.

12. Kang, J. Political Economy of Communication: A Study on Structural Barrier of Communication. In Communication Crisis in the Korean Society; Korean Society for Journalism and Communication Studies, Ed.; Communication Books: Seoul, Korea, 2011; pp. 65-89. ISBN 9788964061862. (In Korean)

13. Kang, M. Media War and the Crisis of Journalism Practices. Korean J. Journal. Commun. Stud. 2004, 48, 319-421. (In Korean)

14. Nam, S. Media Crisis and Professional Journalists' Responsibilities. Kwanhun J. 2009, 113, 89-109. (In Korean)

15. Patterson, T. Out of Order; Vintage Books: New York, NY, USA, 1994; ISBN 0679755101.

16. Kim, J. Editorial Tone of Major Korean Newspapers toward the Sunshine Policy during the Kim Dae Joong Government. Korean Political Sci. Rev. 2003, 37, 197-218. (In Korean)

17. Lee, W. Ideological Tendency and Assessment of the Government Policy through Reporting South-North Korea Issue: Comparative Analysis of Editorials under Kim Young-Sam and Kim Dae-Jung Administrations. Korean J. Commun. Inf. 2006, 35, 329-361. (In Korean)

18. Song, Y. A Study on the Korean Newspapers' Objectifying Strategies. Korean J. Journal. Commun. Stud. 2007, 51, 229-251. (In Korean)

19. Choi, H. A Study on the Diversity of Korean Newspapers: Analyzing the Tendencies of Covering Three Major Issues. Korean J. Journal. Commun. Stud. 2010, 54, 399-426. (In Korean)

20. Kim, K.; Noh, G. A Comparative Study of News Reporting about North Korea on Newspapers in South Korea. Korean J. Journal. Commun. Stud. 2011, 55, 361-387. (In Korean)

21. Koh, Y. An Analysis of News Reports about the Scandals of the Presidents' Relatives and In-laws': A News Frame Approach. Commun. Theor. 2007, 3, 156-195. (In Korean)

22. Kim, Y.; Lim, Y. An Analysis of News Reports about Government-Media Relationships and Media Policies: Comparison of News Contents under Noh-Lee Governments. Korean J. Journal. Commun. Stud. 2009, 53, 94-115. (In Korean)

23. Kim, I. A Study on the News Frame Analysis of 2008 Candlelight Protesting: Focusing on the Ideological Polarization of Main Newspapers. Ph.D. Thesis, Kyung Hee University, Seoul, Korea, 2010. (In Korean)

24. Kim, S.; Kim, C.; Kim, H. Discursive Politics of the Media and Economic Crisis: A Case Study about 'Korea's September Crisis in 2008'. Korean J. Commun. Inf. 2010, 50, 164-185. (In Korean)

25. Park, D.; Cho, Y.; Hong, J. A Qualitative Study of News Source-Reporter Relations: On the Problems of Beat Reporting System. Korean J. Commun. Stud. 2001, 45, 367-397. (In Korean)

26. Hong, J.; Kim, K. The Influence of the Ideological Tendency of the Press on the Theme and the Tone of the Press Related with New Media Policy. J. Korea Contents Assoc. 2017, 17, 162-177. (In Korean)

27. Entman, R. Framing: Toward Clarification of a Fractured Paradigm. J. Commun. 1993, 43, 51-58. [CrossRef]

28. Price, V.; Tewksbury, D. News Values and Public Opinion: A Theoretical Account of Media Priming and Framing. In Progress in Communication Sciences; Barnett, G., Boster, F., Eds.; Ablex: New York, NY, USA, 1997; Volume 13, pp. 173-212, ISBN 9781566402770.

29. Scheufele, D.; Tewksbury, D. Framing, Agenda Setting, and Priming: The Evolution of Three Media Effects Models. J. Commun. 2007, 57, 9-20. [CrossRef]

30. d'Angelo, P. News Framing as a Multiparadigmatic Research Program: A Response to Entman. J. Commun. 2002, 52, 870-888. [CrossRef]

31. Pan, Z.; Kosicki, G. Framing Analysis: An Approach to News Discourse. Political Commun. 2007, 10, 55-75. [CrossRef]

32. Fillmore, C.; Atkins, B. Toward a Frame-Based Lexicon: The Semantics of RISK and its Neighbors. In Frames, Fields and Contrasts: New Essays in Semantic and Lexical Organization; Lehrer, A., Kittay, E., Eds.; Lawrence Eribaum Associates: Hillsdale, NJ, USA, 1992; pp. 75-102, ISBN 9780805810899.

33. Nerlich, B.; Koteyko, N. Carbon Reduction Activism in the UK: Lexical Creativity and Lexical Framing in the Context of Climate Change. Environ. Commun. 2009, 3, 206-223. [CrossRef] 
34. Degani, M. Values and Lexical Preferences in Obama's Speeches. In Framing the Rhetoric of a Leader; Palgrave Macmillan: London, UK, 2015; pp. 202-224, ISBN 9781349501014.

35. Newman, M.E.J.; Barabási, A.; Watts, D.J. The Structure and Dynamics of Networks; Princeton University Press: Princeton, NJ, USA, 2006; ISBN 9780691113579.

36. Barabási, A. Chapter 2 Graph Theory. In Network Science; Cambridge University Press: Cambridge, UK, 2016; ISBN 9781107076266.

37. Almgren, K.; Kim, M.; Lee, J. Extracting Knowledge from the Geometric Shape of Social Network Data Using Topological Data Analysis. Entropy 2017, 19, 360. [CrossRef]

38. De Saussure, F. Course in General Linguistics; Columbia University Press: New York, NY, USA, 2011; ISBN 9780231157261.

39. Sowa, J. Principles of Semantic Networks; Morgan Kaufmann: San Mateo, CA, USA, 1991; ISBN 1558600884.

40. Helbig, H. Knowledge Representation and the Semantics of Natural Language; Springer: Berlin, Germany, 2006; ISBN 9783540299660.

41. Drieger, P. Semantic Network Analysis as a Method for Visual Text Analytics. Procedia-Soc. Behav. Sci. 2013, 79, 4-17. [CrossRef]

42. Carley, K.; Pamquist, M. Extracting, Representing, and Analyzing Mental Models. Soc. Forces 1992, 70 , 601-636. [CrossRef]

43. Doerfel, M. What constitutes semantic network analysis? A comparison of research and methodologies. Connections 1998, 21, 16-26.

44. Johnston, H. A Methodology for Frame Analysis: From Discourse to Cognitive Schemata. In Social Movements and Culture; Johnston, H., Klandermans, B., Eds.; UCL Press: London, UK, 1995; pp. 217-246, ISBN 0816625743.

45. Doerfel, M.; Barnett, G. A Semantic Network Analysis of the International Communication Association. Hum. Commun. Res. 1999, 25, 589-603. [CrossRef]

46. Jiang, K.; Barnett, G.; Taylor, L. Dynamics of Culture Frames in International News Coverage: A Semantic Network Analysis. Int. J. Commun. 2016, 10, 3710-3736.

47. Schultz, F.; Kleinnijenhuis, J.; Oegema, D.; Utz, S.; van Atteveldt, W. Strategic Framing in the BP Crisis: A Semantic Network Analysis of Associated Frames. Public Relat. Rev. 2012, 38, 97-107. [CrossRef]

48. Motta, G.; Baden, C. Evolutionary Factor Analysis of the Dynamics of Frames: Introducing a Method for Analyzing High-dimensional Semantic Data with Time-changing Structure. Commun. Methods Meas. 2013, 7, 48-82. [CrossRef]

49. David, C.; Legara, E.F.T.; Atun, J.M.L.; Monterola, C.P. News Frames of the Population Issue in the Philippines. Int. J. Commun. 2014, 8, 1247-1267.

50. Chosun Ilbo. Available online: www.chosun.com (accessed on 31 October 2018).

51. JoongAng Ilbo. Available online: http:/ /joongang.joins.com (accessed on 31 October 2018).

52. The Hankyoreh. Available online: www.hani.co.kr (accessed on 31 October 2018).

53. The Kyunghyang Shinmun. Available online: www.khan.co.kr (accessed on 31 October 2018).

54. Modified from Korea Audit Bureau of Certification, The Number of Paid Circulation of Daily Newspapers in 2017. Available online: http:/ / www.kabc.or.kr/about/notices/100000002623?param.page=\&param. category $=\&$ param.keyword $=$ (accessed on 26 September 2018). (In Korean)

55. Chung, S. External Images of the EU: Comparative Analysis of EU Representations in Three Major South Korean Newspapers and Their Internet Editions. Ph.D. Thesis, University of Canterbury, Christchurch, New Zealand, 2013.

56. Chosun.com. Are Choi Ryong-hae's Visit to PyeongChang and Supports to North Korean the Violation of Sanction against North Korea? 5 January. Available online: http://news.chosun.com/site/data/html_dir/ 2018/01/05/2018010500248.html (accessed on 27 August 2018).

57. Chosun.com. Violation against the Sanction in Case of Supporting North Korean Team's Stay, Ship or Airplanes to PyeongChang. 11 January. Available online: http://news.chosun.com/site/data/html_dir/ 2018/01/11/2018011100310.html (accessed on 27 August 2018).

58. Chosun.com. [Opinion] Can North-South Talks Reach the Disestablishment of North Korean Nuclear Weapons after PyeongChang Olympics. Available online: http:/ / news.chosun.com/site/data/html_dir/ 2018/01/09/2018010903080.html (accessed on 1 October 2018). 
59. Chosun.com. [Public Opinion] North-South Talks, We Should Welcome but should not be Moved. Available online: http://news.chosun.com/site/data/html_dir/2018/01/09/2018010903111.html (accessed on 1 October 2018).

60. Chosun.com. [Opinion] If there is no Taegukgi at the Opening Ceremony of PyeongChang Olympics. Available online: http://news.chosun.com/site/data/html_dir/2018/01/04/2018010403144. html (accessed on 27 August 2018).

61. Hani.co.kr. Around North Korea's New Year's Address, The Minjoo Party of Korea and People's Party "Welcomed" but the Liberty Korean Party Perceived it as "Mockery". Available online: http:/ /www.hani.co. $\mathrm{kr} /$ arti/PRINT/825903.html (accessed on 1 October 2018).

62. Hani.co.kr. Joint March with Holding Korean Unification Flag ... North and South open PyeongChang of Peace. Available online: http:/ / www.hani.co.kr/arti/PRINT/827025.html (accessed on 1 October 2018).

63. Khan.co.kr. [Opinion] Trump, Utilise North-South Talks as an Entrance to North-US Talks. Available online: http://news.khan.co.kr/kh_news/khan_art_view.html?art_id=201801052117005 (accessed on 1 October 2018).

64. Hani.co.kr. Ri Son-gwon Began His Talk with Saying "the Present to Our People," Cho Myoung-gyon Responded with Saying "Well Begun is Half Done”. Available online: http:/ / www.hani.co.kr/arti/PRINT/ 827042.html (accessed on 1 October 2018).

65. Khan.co.kr. The Synergy Coming Out of North Korea's Participation in PyeongChang Olympics. Available online: http:/ / sports.khan.co.kr/olympic/2018/pg_view.html?art_id=201801011837003\&sec_id= 530601 (accessed on 1 October 2018).

66. Hani.co.kr. Special Law on Supporting Unified Korean Team of PyeongChang Olympics, which was Supported by the Liberty Korean Party during MB Administration. Available online: http:/ / www.hani.co. $\mathrm{kr} /$ arti/politics/assembly/828755.html (accessed on 1 October 2018).

67. Korea Gallup. Gallup Report. Available online: http://www.gallup.co.kr/gallupdb/report.asp?pagePos= $4 \&$ selectyear $=\&$ search $=\&$ searchKeyword $=$ (accessed on 12 September 2018).

68. Bang, J. The roles of News Reports for recovering the homogeneity after the unification. In Korean Society for Journalism E Communication Studies; Symposium \& Seminar: Seoul, Korea, 1995; pp. 17-49. (In Korean)

69. Choi, J.; Ha, J. News Frames of Korean Unification Issues: Comparing Conservative and Progressive Newspapers. Korean J. Commun. Stud. 2016, 24, 121-145. (In Korean)

70. Castell, M. The Rise of Network Society; Blackwell Publishers: Oxford, UK, 2000; ISBN 0631221409.

71. Jenkins, H. Convergence Culture: Where Old and New Media Collide; New York University Press: New York, NY, USA, 2006; ISBN 9780814742815.

72. Lim, J. Candlelight and Media: The Mode of Convergence Media and the Emergence of Individualized Mass. Korean J. Humanit. Soc. Sci. 2011, 35, 97-122. (In Korean)

73. Song, T. The Multitude's Foreign Policy Debates and its Collective Behaviour through Social Media: The Impact of Changing Communication Environment on the Public's Foreign Policy Attitudes. Korean J. Int. Stud. 2013, 53, 41-87. (In Korean)

74. Hardt, M.; Negri, A. Empire; Harvard University Press: Cambridge, MA, USA, 2000; ISBN 0674006712.

75. Hardt, M.; Negri, A. Multitude: War and Democracy in the Age of Empire; Penguin Press: New York, NY, USA, 2004; ISBN 1594200246.

76. Wellman, B. Physical Place and Cyberspace: The Rise of Personalized Network. Int. J. Urban Reg. Res. 2001, 25, 227-252. [CrossRef]

77. Morley, D. Media, Modernity, Technology: The Geography of the New; Routledge: London, UK, 2007; ISBN 0415333423.

78. Levy, P. Collective Intelligence: Mankind's Emerging World in Cyberspace; Plenum Trade: New York, NY, USA, 1997; ISBN 0738202614.

(C) 2018 by the authors. Licensee MDPI, Basel, Switzerland. This article is an open access article distributed under the terms and conditions of the Creative Commons Attribution (CC BY) license (http://creativecommons.org/licenses/by/4.0/). 